\title{
2 An Edition of Cambridge Ms. Add. 1680.8
}

This manuscript bundle of 46 palm-leaves ${ }^{1}$ with five lines is the earliest surviving witness of the South Asian Dhäranissamgraha tradition and the only palmleaf compendium known. It is a challenging case because, as Bendall 1883: 169 suggests, these leaves are likely to belong to at least three different collections due to the variations regarding the layout of lines around the string-holes and foliation, which latter is frequently broken off. Since no final colophon remains on any of the leaves we cannot be certain about the title of these collections and their date can only be estimated on a palaeographical basis which points to the $12^{\text {th }}-13^{\text {th }}$ centuries. Note that on folio $1680.8 .3 .1 \mathrm{r}$ there is a donor's name, Śrāvīryaśriksṣuna, after the text of the Niyatakarmakșayaṃkari-nāma-dhāraṇi, however, this is probably a copied name and not the actual sponsor of the manuscript. $^{2}$ On folio 1680.8.1.3v an eight-armed Ușnịịavijayā is painted and on folio 1680.8.1.15r Aștamahābhayā-Tārā is depicted as texts related to these goddesses run in these leaves. ${ }^{3}$

The provenance of this bundle is debatable. While the hook-topped script is likely to indicate Nepalese origins, the two surviving illustrations including string-hole decoration point towards Eastern India. Consequently it is hard to establish where exactly these manuscripts come from. There are a few possible scenarios, for example, that production involving Eastern Indian artists or influences happened in Nepal or these leaves were created in the lowlands perhaps by Nepalese scribes and then taken to the Kathmandu Valley. In any case, it is likely that South Asian Dhâranissamgraha traditions used to be current outside Nepal as well, which suspicion is also supported by the evidence that comparable collections were used across Buddhist lands of Asia.

As for the contents of these leaves, now with their complete edition we can gain a more thorough glimpse than earlier. ${ }^{4}$ Still the tables of contents presented below are somewhat tentative because it is problematic to identify some texts without colophons or to establish the precise sequence of the surviving folios given their often fragmentary condition, the occasionally repeated foliation or the complete lack thereof. For pagination I have followed the Cambridge Sanskrit Manuscripts Project online arrangement and numbering of leaves even though these

1 Bendall 1883: 169 mentions 45 leaves.

2 Cf. the copied donor's name in the edition of Add. 1326, too: a certain Līlādevikā appears on folios $84 \mathrm{v}$, 91r and $94 \mathrm{v}$.

3 There are no further illuminations surviving.

4 Bendall 1883: 169-170 lists 28 colophons.

2 Open Access. (C) 2021 Gergely Hidas, published by De Gruyter. (c))BY-NC-ND This work is licensed under the Creative Commons Attribution-NonCommercial-NoDerivatives 4.0 International License. https://doi.org/10.1515/9783110713367-002 
are expressly provisional. ${ }^{5}$ Where possible, new suggestions for the sequence of folios have been given. ${ }^{6}$ At the moment it seems that altogether 59 different texts survive in this manuscript bundle. Forty-six have been identified while the title of 13 pieces remain unconfirmed. Four scriptures are included twice in these leaves: the Karṇajāpā-nāma-dhāraṇī, Koṇ̣̂ā-nāma-dhāraṇì-caityakaraṇa-vidhi, Mahāśrīnāma-dhāraṇi and the Vajrottarā-nāma-dhāraṇi and there are two different texts bearing the same title, Jātismarā-nāma-dhārañī. About a third of all these texts is included in the earliest known paper Dhäraṇisaṃraha manuscript, Cambridge Add.1326.

\subsection{Contents}

Add.1680.8.1 $1^{7}$

1. 2v Anantabuddhakṣetraguṇodbhāvana-dharmaparyāya

[A part of a chapter of the Buddhāvatamsaka ${ }^{8}$ ]

2. 3v Uṣnịiṣavijayā-nāma-dhāraṇīī [100]

[The first part of the text. Continues at Add. 1680.8.1.21]

3. $4 \mathrm{r}$ Halāhala-hṛdaya ${ }^{10}$

[The very end of the text. Probably continued from Add. 1680.8.1.16]

4. $4 r$ Unidentified text

[A brief purificatory text dedicated to Sumerukalparāja. Shares parts with Ādikarmapradīpa 33] ${ }^{11}$

5. 4r Jātismarā-nāma-dhāraṇī [36]

[The complete text; somewhat shorter than the version in Add. 1326. Different from the one with similar title in Add. 1680.8.3.11]

5 An online description and complete digital reproduction is available at https://cudl.lib.cam. ac.uk/view/MS-ADD-01680-00008-00001/1, https://cudl.lib.cam.ac.uk/view/MS-ADD-0168000008-00002/1, https://cudl.lib.cam.ac.uk/view/MS-ADD-01680-00008-00003/1 (accessed March 2020).

6 Note that folio Add.1680.8.2.11v most likely continues on Add.1680.8.1.Xr, which raises questions about the assumed tripartite division of the bundle.

7 Editions known to me are indicated in the footnotes. Corresponding text numbers in Cambridge Ms. Add. 1326 are given in square brackets.

8 Cf. Hamar 2015: 92, 94 and Skilling and Saerji 2012.

9 Cf. Müller and Nanjio 1884, Yuyama 2000, Hidas 2020.

10 Cf. parts of Sādhanamālā No. 28. (Bhattacharyya 1925-1928: 66-71).

11 Cf. Takahashi 1993: 152. 
6. $4 \mathrm{v}$ Unidentified text

[A short protective spell along with ritual instructions]

7. $\quad$ 4v Uṣnīṣavijayā-nāma-dhāraṇī [100]

[Probably the very beginning of the text to be continued at Add.1680.1.2]

8. 4bisv Nārāyaṇaparipṛcchā-mahāmāyāvijayavāhinīin ${ }^{12}$ [91]

[The first half of the text; somewhat different from the published one]

9. 7r Aștamahābhayatārā-sādhana ${ }^{13}$

[The very end of the text. Continued from Add. 1680.8.1.22]

10. 9r Sarvajinadhāturatnakaraṇḍaka-nāma-bhagavad-

āryāvalokiteśvarasya nāmāṣțottaraśataka [140]

[The complete text]

11. Piṇ̣̂ikrama-sādhana ${ }^{14}$

[The opening verse]

12. 9r Unidentified text

[A spell for the protection of children with ritual instructions]

13. 9v Karṇajāpā-nāma-dhāraṇī [40]

[The complete text; slightly longer than in Add. 1326 with ritual instructions added. Similar to Add. 1680.8.3.38]

14. 9bisr Șaṇmukhī-nāma-dhāraṇīi ${ }^{15}[44]$

[The second half of the text. Continued from 1680.8.1.25]

15. 9bisv Bhadracari-praṇidhāna ${ }^{16}[70]$

[The beginning of the text]

16. 9trisv Halāhala-hṛdaya

[The last part of Sādhanamālā No. 28 with ritual instructions added. Probably continued at Add. 1680.8.1.3]

17. $13 r$ Ușṇīṣavijayā-sādhana ${ }^{17}$ [169]

[The complete text]

18. 13r Vasudhārā-dhāraṇīi ${ }^{18}$ [62]

[A section of the text]

12 Cf. Banerjee 1941.

13 Cf. Sādhanamālā No. 99. (Bhattacharyya 1925-1928: 207-208).

14 Cf. de la Vallée Poussin 1896: 1-14.

15 Cf. Mimaki 1977.

16 Cf. Vaidya 1960a: 428-29.

17 Cf. Sādhanamālā No. 211. (Bhattacharyya 1925-1928: 417-418).

18 Cf. Dhīh 2007. 
19. $13 v$ Vajrasarasvatī-sādhana ${ }^{19}$

[The complete text]

20. $14 \mathrm{v}$ Unidentified text

[Various spells dedicated to the Gạ̣ḍavyūha and Samādhirāja, furthermore Mahāpratisarā, Vajrapāṇi and another one with ritual instructions. Cf. Add.1680.8.3.8]

21. 15r Uṣṇiṣavijayā-nāma-dhāraṇī [100]

[The very end of the text starting at Add.1680.8.1.2]

22. $15 \mathrm{v}$ Aștamahābhayatārā-sādhana

[The almost complete text. Continued at Add. 1680.8.1.9]

23. $19 \mathrm{v}$ Maitreyanāthasya +++++

[Verses with references to the six pāramis and ten bhūmis]

24. Xr Gāthādvaya-dhāraṇī [43]

[The second half of the text. Continued from Add. 1680.8.2.4]

25. Xv Ṣaṇmukhī-nāma-dhāraṇī [44]

[The first half of the text. Continues at 1680.8.1.14]

Add.1680.8. $2^{20}$

1. 9r Mahāmaṇivipulavimānasupratișțhitaguhyā-nāma-dhāraṇīin

[The very end of the text. This part does not survive in the edited Gilgit fragments]

2. $9 v$ Unidentified text

[The beginning of a text dedicated to Vajraśrnnkhalā with a spell. Perhaps related to Add. 1680.8.3.7]

3. 11r Samādhirājasūtra ${ }^{22}$

[The beginning of chapter 3, the Bhūtagunavarṇaprakāśanaparivarta]

4. 11v Gāthādvaya-dhāraṇī [43]

[The first part of the text. Continued at Add. 1680.8.1.24]

19 Note that this text is titled Suklaprajñāpāramitāsādhana in Sādhanamālā No. 151. (Bhattacharyya 1925-1928: 310-311).

20 Editions known to me are indicated in the footnotes. Corresponding text numbers in Cambridge Ms. Add. 1326 are given in square brackets.

21 Cf. Matsumura 1983.

22 Cf. Vaidya 1961b: 13. 


\section{Add.1680.8. $3^{23}$}

1. 1r Grahamātṛkā-nāma-dhāraṇi $\bar{i}^{24}[103,177]$

[The second half of the spell. Continued from Add. 1680.8.3.12]

2. 1r Niyatakarmakṣayaṃkarī-nāma-dhāraṇī

[A single invocation and spell]

3. 1v Mahāśrī-nāma-dhāraṇī

[The beginning of the text. Invocation to Tārā. The Buddha dwells in Sukhāvatī and teaches the twelve names of Mahāśrī along with a spell to Mañjuśrī and Avalokiteśvara for the sake of prosperity. Similar to Add. 1680.8.3.40]

4. 2r Mārīcī-nāma-dhāraṇīi ${ }^{25}$ [102]

[The end of the text]

5. $2 \mathrm{v}$ Unidentified text

[A short spell with tantric references]

6. 2v Samantabhadrapratijñā-nāma-dhāraṇi

[The first part of the text with invocations, a spell section and vows. Continues at Add. 1680.8.3.9]

7. 3r Vajra++lā-nāma-mahāvidyā ${ }^{26}$

[The end of a text with enumerations of benefits. Perhaps related to Add. 1680.8.2.2]

8. $3 v$ Unidentified text

[Various brief spells including the Jātismarā and Vajrottarāhṛdaya. Cf. Add.1680.8.1.20]

9. 4r Samantabhadrapratijñā-nāma-dhāraṇī

[The second part of the text with vows, a spell section and a ritual manual. Continued from Add. 1680.8.3.6]

10. 5r Așțamahābhayatāraṇī-nāma-dhāraṇī [118]

[The complete text; longer than in Add. 1326 with enumerations of benefits]

11. $5 r$ Jātismarā-nāma-dhāraṇī

[The complete text; different from the one with similar title in Add.1680.8.1.5 and Add.1326 [36]]

12. $5 v$ Grahamātṛkā-dhāraṇī $[103,177]$

[The first part of the spell. Continues at Add. 1680.8.3.1]

23 Editions known to me are indicated in the footnotes. Corresponding text numbers in Cambridge Ms. Add. 1326 are given in square brackets.

24 Cf. Dhīh 2005.

25 Cf. Dhīh 2006.

26 Perhaps Vajraśṛnkhhalā? 
13. 6v Jāñgulī-mahāvidyā

[A section of the text against snakebite with spells and benefits. Probably continues at Add. 1680.8.3.23]

14. 10v Unidentified text

[The latter part of a spell and a fragmentary sentence with the benefits of this text perhaps related to Vajraśṛnkhalā]

15. 12r Vajrottarā-nāma-dhāraṇī

[The very end of this text. Similar to Add. 1680.8.3.26]

16. 12r Koṇụā-nāma-dhāraṇī-caityakaraṇa-vidhi

[Various invocations, spells and ritual instructions for gifts and a caitya ceremony. Similar to Add. 1680.8.3.28]

17. 13v Cintāmaṇi-nāma-dhāraṇi [33]

[Shorter sections of various spells followed by the Cintāmaṇi-nāma-dhāraṇi along with the Vimaloṣṇiṣa-dhāraṇī]

18. 14r Lakṣa-nāma-dhāraṇī

[The complete text of the Bodhigarbhālaṃkāralakṣa-dhāraṇī. ${ }^{27}$ This is the only manuscript witness of the text known to me]

19. 14v Dṛșțapratyayah-śrutidharā-nāma-dhāraṇi

[A short text dedicated to Avalokiteśvara. Invocations, a spell and ritual instructions]

20. 15v Cundā-dhāraṇī-sarvatathāgatahṛdayā [110]

[The complete text titled Cundābhațạarikāyā rakṣāmantra in Add. 1326 introduced by the eight names of Avalokiteśvara]

21. 16v Hemāñā-nāma-dhāraṇī [86]

[The complete text]

22. $16 \mathrm{v}$ Unidentified text

[A short text with an invocation to Akșobhya, a spell sharing features with a part of Add. 1326 [48], and benefits]

23. $17 r$ Jāṅgulī-mahāvidyā

[The very end of the text. Probably continued from Add. 1680.8.3.13]

24. $17 \mathrm{v}$ Jāngulyā bhagavatyāh kalpa ${ }^{28}$

[The complete text with spells and ritual instructions for treating snakebite]

25. 17bisr Akṣobhyā-nāma-dhāraṇi

[The very end of a text unrelated to Add. 1326 [4]]

27 Cf. Schopen 1985 and Strauch 2009, Hidas 2021.

28 Cf. Sādhanamālā No. 121. (Bhattacharyya 1925-1928: 251-252). 
26. 17bisr Vajrottara-nāma-dhāraṇī

[A short text with an invocation to Vajrottararāja, a spell and ritual instructions against illnesses. Similar to Add. 1680.8.3.15]

27. 17 bisv +++++++ nāma-dhāraṇi

[A short lacunose text with an invocation and spell]

28. 18r Koṇḍa-nāma-dhāraṇī-caityakaraṇa-vidhi

[Various invocations, spells and ritual instructions for gifts and a caitya ceremony. Similar to Add. 1680.8.3.16]

29. 21r Mahādhāraṇī

[A longer and complete dhāraṇī sūtra. The Buddha dwells in Śrāvastī and teaches a string of spells to Ānanda which provide multifold protection and benefits]

30. 22v Buddhahṛdayā-nāma-dhāraṇī

[A longer and complete dhāraṇī sūtra. The Buddha dwells in the Range of Tathāgatas (tathāgatagocara) and teaches a twofold spell with various benefits to an assembly of bodhisattvas]

31. 23r Samantabhadrā-nāma-dhāraṇī

[This text, different from and longer than Add. 1326 [20], contains a spell with brief ritual instructions]

32. 23v Dhātukaraṇḍ̄-nāma-dhāraṇī ${ }^{29}$

[The complete text of the Sarvatathāgatādhișthānaguhyadhātukaraṇḍakamudrā-dhāraṇi. This is the only manuscript witness of the text known to me. After an invocation and the spell taught by the Buddha numerous tathāgatas praise him for this deed]

33. 24v Rucirāñgayaștị-nāma-dhāraṇi

[The beginning and larger part of the text with an invocation, a spell and benefits. Continues at 1680.8.3.43]

34. 25v Svapnaṃdadā-nāma-dhāraṇī

[The latter section of the text with a part of the spell and ritual instructions]

35. $25 \mathrm{v}$ Viśeșavatī-dhāraṇi ${ }^{30}$

[The beginning of the text. The Buddha in Pāravata land. The first part of a narrative about a bhikṣu called Vapakhyāta. See also Add. 1680.8.3.37 and 42]

36. 26v Unidentified text

[The ritual instructions and benefits section of a text dedicated to Avalokiteśvara]

29 See Schopen 1982 for a study and identification of the Sri Lankan inscriptions with the dhāraṇi section published in Mudiyanse 1967.

30 See Felbur, Harrison and Wiles (forthcoming). 
37. 30v Viśeșavatī-dhāraṇī

[Invocations to buddhas and bodhisattvas along with brief spells. Ritual instructions uttered by Mañjuśrīkumārabhūta primarily to overcome illnesses and to liberate people. See also Add. 1680.8.3.35 and 42]

38. 32r Karṇajāpā-nāma-dhāraṇī [40]

[The very end of this text; similar to Add. 1680.8.1.13]

39. 32r Caityavandanā-nāma-dhāraṇī

[A brief text with invocations, a spell and a description of benefits]

40. 33r Mahāśrī-nāma-dhāraṇī

[The Buddha dwells in Sukhāvatī and teaches the twelve names of Mahāśrī along with a spell to Mañjuśrī and Avalokiteśvara for the sake of prosperity. After the spell ritual instructions and a description of benefits follow with a formal conclusion of the text. Similar to Add. 1680.8.3.3]

41. $33 \mathrm{v}$ Unidentified text

[The beginning of the text. Ritual instructions and a mantra dedicated to Avalokiteśvara for the preparation of pills to eliminate various illnesses]

42. 35v Viśeșavatī-dhāraṇī

[The nidāna continued. The bhikṣu in conversation with Mañjuśrīkumārabhūta who teaches about illnesses afflicting people in Jambudvipa. See also Add. 1680.8.3.35 and 37]

43. 36r Rucirāṅgayașṭi-nāma-dhāraṇī

[The end of the text with ritual instructions. Continued from 1680.8.3.33]

44. 36r Sarvamañgalā-nāma-dhāraṇī [39]

[The text with brief ritual instructions and a description of benefits added which are not present in Add. 1326]

45. 36v Sarvarogapraśamanī-nāma-dhāraṇī [144]

[After an invocation to Heruka a spell follows which eliminates all illnesses. This text is referred to as originating from the Vajraśikharodbhavatantra]

46. 36v Unidentified text

[The very beginning of a text] 


\subsection{Editorial policy}

This edition provides a slightly standardized and structured version of the text present in the manuscript bundle. There are some marginal corrections and additions by a second hand. Occasionally minor corrections have been made by the editor to improve readings.

\subsection{Silent standardizations}

Geminations after $r$ have been standardized

Degeminations before a semivowel have been standardized

Sibilants have been given in their standard form

Final anusvāras before vowels or at the end of sentences have been changed to $m$ Homorganic nasals have been changed to anusvāras when needed Variations between $\mathrm{a} / \overline{\mathrm{a}}, \mathrm{i} / \overline{\mathrm{i}}, \mathrm{u} / \overline{\mathrm{u}}$ have been standardized The lack of avagrahas has not been indicated

\subsection{Symbols and abbreviations}

$+\quad$ a broken off or illegible akșara

[x] restoration of a partly broken off a kșara

$\leq \quad$ a special sign seemingly functioning as a line-filler

$<\mathrm{x}\rangle \quad$ folio numbering as given online in the Cambridge digital library

ac. a reading in the manuscript before alteration (ante correctionem)

pc. a reading in the manuscript as altered (post correctionem)

corr. correction by the editor

ms. an original reading in the manuscript 


\subsection{Ms. Add.1680.8.1}

Extent: 15 folios. Folios are numbered online as 2, 3, 4, 4bis, 7, 8, 9, 9bis, 9tris, $10,13,14,15,19$ and there is one last unnumbered folio.

[1] <2r> buddhakṣetra | eka[ṃ rātriṃdivasaṃ] yat khalu puna $\leq r$ bho jinaputrākāṣāpaddhajāyāṃ lokadhātau kalpaṃ tad avaivartikacakranirghoṣāyām lokadhātau bhagavataḥ sunicitapadma[praphu]llitagātrasya tathāgatasya buddhakṣetre ekaṃ rātriṃ divasaṃ yat khalu puna bho jinaputrāḥ | avaivartikacakranirghoșāyāṃ lokadhātau kalpaṃ tad dhi rajāyām lokadhātau bhagavato dha[rmadhva]jasya tathāgatasya buddhakṣetre ekaṃ rātrim divasaṃ yat khalu punar bho jinaputrādhirajāyāṃ lokadhātau kalpaṃ tat pradīpāyāṃ lokadhātau bhagavatạ̣ siṃhasya tathāgatasya buddha[kṣe]tre ekam rātrim divasam yat khalu punar bho jinaputrāh pradīpāyām lokadhātau kalpaṃ tat suprabhāyām lokadhātau bhagavato vairocanasya tathāgatasya buddhakṣetre ekam rātriṃ di[vasam yat khalu punar] bho jinaputrāḥ suprabhāyāṃ lokadhātau kalpaṃ tad duratikramāyāṃ lokadhātau bhagavato dharmaraśmipraphullitagātrasya tathā[gatasya buddhakṣetre ekam <2v> rātrim divasaṃ] yat khalu punar bho jinaputrā duratikramāyām lokadhātau kalpaṃ buddhavyūhāyāṃ lokadhātau bhagavataḥ sarvābhistumatiraśmirājasya tathāgata[sya buddhakṣetre ekaṃ rātriṃ di]vasaṃ yat khalu punar bho jinaputrā vyūhāyāṃ lokadhātau kalpaṃ tadā daśamaṇḍalanirghoṣāyāṃ lokadhātau bhagavataś candrabuddhe tathāgatasya buddhakṣetre ekam rātrim [divasam yat] khalu punar bho jinaputrāḥ lokadhātau kalpagaṇanāpraveśena pariphullāṃ daśabuddhakṣetraparamāntarajaḥsamāṃ buddhakṣetraśatasahasrāṇy atikramya tataḥ padmaśriyā lokadhātau bhagavato bhadraśriyasya tathāgatasya buddhakṣetre ekaṃ rātriṃ divasaṃ yatra samantabhadracaritānāṃ bodhisattvānāṃ bhūmiparikarmaviśeșaḥ | yaḥ kaścid bho jinaputrā kulaputro vā kuladu[hitā vā] imaṃ tathāgatānām anantabuddhakṣetraguṇodbhāvanaṃ dharmaparyāyam udgrahīṣyati dhārayiṣyati vācayișyati paryavāpsyati yonisaś ca manasi+

[2] <3r > ++++++++[șavijayāyai] ॥

om namo bhagavate sarvatrailokyaprativiśișțāya buddhāya te namaḥ | tadyathā oṃ bhrāṃ bhrāṃ bhrāṃ śodhaya śodhaya viśodhaya viśo[dhaya asamasa]mantāvabhāsaspharaṇagatigaganasvabhāvaviśuddhe |

18 buddha-] corr.; bud- ms. 23 -dhātau] corr.; -dhātta ms. 31 Probably continued from 4v. 
abhiṣiñcontu māṃ sarvatathāgatāḥ | sugatavaravacanāmṛtābhiṣekair mahāmudrāmantrapadaiḥ | āhara āhara āyuhsaṃdhāraṇe śodhaya śodhaya viśodhaya viśodhaya gaganasvabhāvaviśuddhe | uṣnīṣavijayapariśuddhe | sahasraraśmisaṃcodite | sarvatathāgatā[valokini | șaṭpāra]mitāparipūraṇi | sarvatathāgatamātre | daśabhūmipratișṭhite | sarvatathāgatahṛdayādhișthānādhișțhite | mudre mudre mahāmudre va[jrakāya] saṃhatanapariśuddhe | sarvakarmāvaraṇaviśuddhe | pratinivartayāyurviśuddhe | sarvatathāgatasamayādhișthānādhișțhite | oṃ muni muni mahāmuni | [vimuni vimuni] <3v> mahāvimuni | mati mati mahāmati | mamati sumati tathatābhūtakoțipariśuddhe | visphuṭabuddhiśuddhe | he jaya [jaya vijaya] vijaya | smara smara | sphara sphara sarvabuddhādhișțhānādhișṭhite | śuddhe suddhe buddhe buddhe | vajre vajre | mahāvajre | suva[jre vajraga]rbhe jayagarbhe vijayagarbhe vajrajvālāgarbhe vajrodbhave vajrasambhave vajre vajriṇi | vajram bhavatu mama śarīram sarvasattvā++++++śsuddhir bhavatu mama sadā sarvagatipariśuddhiś ca | sarvatathāgatāś ca samāśvāsayantu | budhye budhye | sidhye sidhye |+++++++++ [vibodhaya] | mocaya mocaya | vimocaya vimocaya | śodhaya śodhaya | viśodhaya viśodhaya |

[Uṣnịịavijayā-nāma-dhāraṇī]

[3] $<$ 4r $>++++++++$ tuh |

Ārya-halāhala-hṛdayaṃ samāptam || ||

oṃ hrīḥ hūṃ japamantraḥ || ||

[4] namo bhagavate sumerukalparājāya tathāgatāyārhate samya[ksambuddhāya]

++++kalpe 2 mahākalpe kalpapariśodhane | dakṣinām pariśodhaya svāhā || sakṛd uccāritamātreṇa sumerupramāṇamātram api piṇḍapātādi pariśodhitam bhavati || ||

[unidentified text]

[5] namo bhagavatyai ārya-jātismarāyai || namo bhagvate śākyamunaye tathāgatāyārhate samyaksambuddhāya |

10 tathatā] $p c . ;$ tathā ac. 11 sphara] ac.; sphara ralaraya $p c .18$ Continued on 15r. 19 Continued from 9trisv. 
tadyathā oṃ bhagavati suvrate siddhe susiddhe saānte dānte mokșaṇi mukte vimukte amale vimale nirmale duhkhacchedani dantạ șaștibhir buddhakoțībhir bhāṣite | hiraṇye hiraṇyagarbhe | sarvārthasādhani | sarvatrāpratihate svāhā ||

ya imāṃ dhāraṇị̣̄ dhārayed vācayel likhāpayet | sa

catuhṣaș̣̣ikalpakoṭisahasrāṇi jātismaro bhavati | durgatiṃ nābhijā<4v>nāti | janmani janmani cakravartirājā bhavati | dine dine jāpāt sumerumātraṃ pāpaṃ kṣayaṃ gacchati | asyā dhāraṇyāḥ prabhāvena ||

Ārya-jātismarā-nāma-dhāraṇī samāptā || ||

[6] namah sarvabuddhabodhisattvebhyah oṃ sarvavit pūra 2 sūra 2 āvartābhaye svāhā || vidhir ekasmaraṇamātreṇa sarvatathāgatānāṃ pūjāya sthānaṃ śirasā +++++++++ $\leq \leq \leq$ bhavati | satatajāpena na sā kācin triratnapūjāyānakṛtopacitā bhavati | sarvāśāparipūraṇaṃ sarvakālaṃ japatām | sarvabu[ddhabodhi] sa+++++++dhipra+++sarvadevatāvarjanam | sarvanāgavaśîkaraṇam | sarvasattvaprasādanam | japata ātmarakṣā pararakṣā vā amoghāḥ | sarvabhūtakṛtya ++++++++++++++++++++++++ dhyo bhavati | janamadhye vaśataḥ | asādhitasyaitāni karmāṇi bhavati || ||

[Unidentified text]

[7] namo

[Unidentified text: Uș̣nịṣavijayā-nāma-dhāraniī?]

[8] <4bisr>++dyādharāpsarādibhih śrūyamāno dharmāvalokamukhaṃ nāma dharmaparyāyaṃ deśayāmāsā atha nārāyaṇau 'surair jitaḥ parājitạ̣ saṃtrastas tejobalahīno yena bhagavāṃs te[nopasaṃ]krānta upasaṃkramya bhagavatạ pādau śiraśābhivanditvābhivandya ekānte nyașīdat | ekānte niṣaṇṇạ̣ | sa evam āha | sarvajño 'si bhagavan sarvadarśî | sarvasattvānukampa ++ tad deśayantu me bhagavān dharmaparyāyam | yena devā nāgā yakṣā rākṣasādayo manuṣyā amanuṣyā vā mahatā śastrasampāte saṃgrāme bāhuyuddhabale vā vivāde vā sarve vi[jayino] bhavișyanti ++++++m atra nārāyaṇa bhīto 'si māyādharas tvaṃ nārāyaṇa māyāvĩ tvaṃ mahābalo 'si | anekamāyājālena sattvān vihețhayasi | saṃgrāmavi[jayī] praśnaṃ pari+++++++++++hāhaṃ

21 Probably continued on 3r. 22 Seemingly not this folio follows. 
bhagavan kāmāsurendreṇāsuramāyayā jito 'haṃ parājito 'ham | ubhāś ca devāḥ kecit ++++++++<4bisv> ++++++++bhagavān dharmapa[ryā]yaṃ yena sattvāḥ saṃgrāme vijayino bhaviṣyanti | asurān parājayiṣyante | hīyamāna darpā asurā bhavișyanti | bhagavān āha | bhū[tapūrvaṃ nārā]yaṇa atīte 'dhvani magadhe rohitake parvate ratnaśrīr nāma rājā babhūva | tena kālena tena samayena viśveśvaro nāma tathāgato 'rhan samyaksambuddho vidyācaraṇasampannạ̣ ++ lokavid anuttaraḥ puruṣadamyasārathị̣ sāstā devānāṃ manuṣyāṇāṃ ca buddho bhagavān tasya bhagavato viśveśvarasya sakāśān mayā imāni mahāmāyāvijaya[vā]hinī nāma vidyāmantrapadāny udgṛhītāni dhāritāni vācitāni | paryavāptāny anumoditāni | parebhyaś ca vistareṇa samprakāśitāni | asyā dhāraṇyā prabhāvena nārā[ya]ṇa na kvacic chatrubhayaṃ na durgatibhayam | na vinipātabhayam | na caurabhayaṃ cotpannaṃ navanavativarṣasahasrāṇi dharmeṇa rājyaṃ kārayitvā paścāst sukhena nagarān nagarabhāvaṃ gr

[Nārāyanaparipṛcchā-mahāmāyāvijayavāhinī]

[9] $<7$ r $>$ [bha]yam jagat $\|$

ity Aștamahābhayatārā-sādhanaṃ samāptam || ||

[10] namo lokanāthāya || evaṃ mayā śrutam ekasmin samaye bhagavān āryāvalokiteśvarasya bhavane potalake parvatarājaśikhare nānāvṛkṣasurabhikusumāvakīrṇe jāmbūnandasuvarṇakāñcanāvabhāsai nānāratnāvabhāsavimānabhūmipradeśe viharati sma | anekair devanāgayakṣagandharvāsuragaruḍakiṃnaramahoragair manuṣyāmanuṣyaiḥ śakrabrahmalokapālapramukhair bodhisattvakoținiyutasahasraiś ca sārdhaṃ bhagavān satkṛto [gurukṛ] to mānitaḥ pūjito 'rcito apacāyitạ̣ parivṛtah puraskṛto dharmam deśayati sma | ādau kalyāṇam madhye kalyāṇaṃ paryavasāne kalyāṇaṃ svarthaṃ suvyañjanaṃ kevalaṃ paripūrṇaṃ pariśuddhaṃ paryavadātaṃ brahmacaryaṃ saṃprakāśayati sma | atha khalu brahmādyā devagaṇāḥ yena potalakaparvataśikharas tenopasaṃkānto upasaṃ $<7 \mathrm{v}>$ [kramyāryā]valokiteśvaraṃ bodhisattvaṃ mahāsattvam samstuvanti sma | he bhagavan kṛtakṛtya kṛtakarạiiya apahṛtabhāra | anuprāptasvakārtha parikṣiṇabhavasaṃyo+++++++++muktacitta suvimuktaprajña ājāneya mahānāga sarvacetovaśiparamapāramiprāpta paripūrṇajñānasambhāra uttīrṇabhavakāntāra parahitayatna

16 Continued from 15v. 19 āryāvalokiteśvarasya] $p c$; āryāvalovalokiteśvarasya $a c$. 
mahākaruṇābaddhahṛdaya prajāparamavatsala sukhaprada snehapraș̣tagātra anantasattvottāraṇa kuśalasugatātmaja tribhuvanaikabāndhava vigatarāga vigatadveșa vigatamoha trimalaprahịṇa traividyāpāraga ṣaḍabhijñāprāpta nyagrodhaparimaṇụala dvātriṃśanmahāpurașalakṣaṇa aśītyanuvyañjanālaṃkṛtagātra suvarṇavarṇasūkṣmacchavi prāńśuravadātamūrti navanāgakesarāruṇajațādhara jațākalāpopagūḍhamūrdhni amitābhaprayuktaraśmi suvimuktaraśmi jvalitavyāmaprabha kāñcanādiprasitayaśạ̣ | $\leq<8$ r $>$ suvimalatejạ̣ udayodgīrṇadinakaroṣṇiṣa maṇikanakaprajvalitayajñopavītārdhakāya daśabhūmipravicaya daśapāramitānugatacaraṇa akhạ̣ḍitaśīla acchidraśîla siṃhavikrāntoraska komalalalitagātra vṛṣabhendrekṣaṇagati dakṣiṇāvartaśan̉kha gambhīrāvartanābhi ardhacandrālaṃkṛtatilaka vistīrṇalalāța pralambabāhu nirantarabhrū uttunganāsa kalaśākṛtigrīva dīrghānguliparvāṇi mṛdutāmranakha jvālāvanaddhahasta cakrāṃkṛtapāṇipādatala śaratkamalanibha sūkṣmopacitagātra brahmagambhīrasvara hṛdamgamapriyañga [sa]premaṇīparamasṇīya darśanīya sudarśana kamalābha kamalodbhava kamalasambhava kamalāsana kamalahasta kamaṇụaluvyagrahasta kṛṣnāji[na]dhara akșadhara pūtapavitra pūrvābhilāṣi [amṛtava]rṣa cintāmaṇikalpavṛkṣa sudarśana sarvasattvadhṛtikara prītikara sarvasattvopajīvya buddhanirmāṇakāya sugataveśa $<8 \mathrm{v}>$ dhara sugatadhātudhara ekaikaromasattvasāra kṛtapuṇya kṛtakuśala kṛtaniścaya uttaptavīrya saṃsārātikrānta sarvadharmayauvarājyābhiṣikta tārānugatacaraṇa bhṛkuṭị $\leq++$ dru jayavanta nayavanta smṛtimanta śāntimanta śīlavanta maitrīmanta rūpavanta guṇavanta puṇyavanta bhāgyavanta arthavanta arthānāṃ dātāra saṃśayānāṃ chettāra dharmāṇāṃ pravaktāra lokānāṃ śāstāra paripūrṇacandramaṇḍalamukha sarvaratnakhacitanitambapradeśa suvarṇavarṇayūpasthāyī sūryasahasrātiriktaruciraśarīra brahmendrādinamaskṛta iti | yaḥ kaścid āryāvalokiteśvarasya nāmāṣṭottaraśatena stotreṇa stotropahāraṃ kuryāt tasya pañcānantaryāṇi karmāvāraṇāni parikṣayam gacchanti | sarvamaṇḍalapravișțo [bhavati] | sarvamantrāś ca tasya sidhyanti | anekakalpakoṭisahasrāṇi durgatim nābhigacchati avīcī nu praviśati dine dine prātar utthāya yaḥ paṭhed dhā<9r>[rayed vācayet] +++yed vā tasya kāye kuṣṭhavicarcikā kāsaśvāsādayo na bhavanti sarvavyādhivinirmukto bhavati | janmani janmani jātismaro bhavati | devaputrasadŕśo bhavati | maraṇasamaye sukhāvatyāṃ lokadhātāv upapadyate | jātau jātau cāryāvalokiteśvareṇāvirahito

17 darśanīya] corr.; daśanīya ms. • sudarśana] corr.; sudaśana ms. 19 sudarśana] corr.; sudaśana ms. 36 jātau] corr.; jātā ms. 
bhavati satatajāpena medhāvī bhavati śūro bhavati susvaro bhavati surūpo bhavati ādeyavākyo bhavati | sarvaśāstraviśārado bhavati | yaś cānena stotreṇa stotropahāram kuryāt | tena dvāṣaștigaṇgānadīvālukāsamā buddhā bhagavato vanditāh pūjitāś ca bhavanti samo vipāko nāsti viśeṣaḥ |

Sarvajinadhāturatnakaraṇḍakạ̣ nāma bhagavad āryāvalokiteśvarasya nāmāṣṭottaraśatakaṃ samāptam || || kṛtir iyaṃ brahmaṇaḥ ||

[11] trailokyācāramuktaṃ gaganasamagataṃ sarvabhāvasvabhāvaṃ śuddhaṃ śāntam viviktam paramaśivam ayaṃ yoginām eva <9v > gamyam | durbodhaṃ durvicāraṃ svaparahitatamaṃ vyāpinaṃ nirnimittaṃ vande kāyaṃ jinānāṃ sukham asamasamaṃ nirvikalpaikamūrtim ||

[Piṇụikrama-sādhana]

[12] om siddhị || tvrri trrrrī krrrram ndrrrrra rrrrrrra vrrrra srrrri ddhrrrri hrrrrra vrrrra mrrrrar srrrra ayaṃ mantro raṅgayantrena kharavalikayā likhitvā bālānāṃ kaṇṭhe bāhau baddhvā dhāryaḥ | ahị̣̣̂i pūrmakṣirā vigrahaṇī āmarantu ḍākinī grahamātarā bhūtapretādityo bālānāṃ dvādaśavarṣāṇi yāvat rakṣām karoti saptadurvākalambasahita āryatārāyā daśākṣaramantreṇa ekaviṃśativārān parijapya deyạ̣ | dūrvākalambāni ca potam avarjyā bāle prakṣeptavyāni | dṛșțapratyayạ̣ || ||

\section{[Unidentified text]}

[13] namo jihvottararājāya tathāgatāyārhate samyaksambuddhāya tadyathā om vara vara sarvaratnapratimaṇditaśarīre svāhā || anayā dhāra[ṇyā] maraṇakāl+++karṇajāpo dīyate sa saṃsāraduḥkhebhyo mucyate | sukhāvatī nāma lokadhātāv utpadyata iti ||

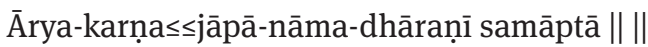

[14] <9bisr> ++++++++++++++șțhitatā | tadyathā | om kṣame kṣame | kṣānte kṣānte | dame dame | dānte dānte | bhadre bhadre | subhadre subhadre | candre candre | sucandre sucandre | candrakiraṇe | candravati || tejo++++++

13 It appears that in this part the original akșaras were deleted and thinner ones inserted with these seed syllables. 13 -valikayā] corr.; -vanikayā ms. 25 Continued from Xv. The left side of the folio is illegible. 
++++++++[sarvakleśaviṣodhani] | sarvārthasādhani | sarvānarthapraśamani | paramārthasādhani | sarvāpāyaviśodhani | kāyaviśodhani | vāgviśodhani | manasam [śodhani] +++++++

+++ [kulaputro vā] kuladuhitā vā imāṃ șaṇmukhịm nāma dhāraṇị̣ triṣkṛtvā rātre triṣkṛtvā divasasya++vartayisyati sa sarvakarmāvaraṇāni ++++ kṣipram anuttarā samyaksambodhim abhisambhotsyate || idam avocad bhagavān āttamanasas te ca bodhisattvā mahāsattvā bhagavato bhāṣitam abhyanandann iti || ||

++++ nāma-dhāraṇī samāptā || ||

[Ṣaṇmukhī-nāma-dhāraṇī]

[15] namah samantabhadrāya | atha khalu samantabhadro bodhisattvo mahāsattva etān eva lokadhātuparamparān abhilā++++<9bisv>pyabuddhakṣetraparamāṇurajaḥsamān kalpān kalpaprasarān abhidyotayamāno bhūyasyā mātrayā gāthābhi[gī] tena prạ̣idhānam akārṣīt || || yāvat keci+++++ke sarvatṛyadhvagatā narasiṃhāḥ | tān ahu vandami sarvi-y-aśeșān kāyatu vāca manena prasannạ̣ || kṣetrarajopamakāyapraṇāmaiḥ sarvajinān karomi praṇā+ | sarvaji+++khe[na manena bhadraca]ripraṇidhānabalena \| ekarajāgri rajopamabuddhān buddhasutāna niṣaṇṇaku madhye | evam aśeșata dharmatadhātum sarvadhimucyami pūrṇajinebhị || +++++++++++mudrān sarvasvarāṅgasamudrarutebhị̣ | sarvajināna guṇān bhaṇamānas tān sugatān stavamī ahu sarvān || $\leq \leq \leq \leq \leq \leq \leq$ puṣpavarebhi ca mālyava++++++++++bhị | dīpavarebhi ca dhūpavarebhih pūjana teșa jināna karomi || vastravarebhi ca gandhavarebhiś cūrṇapuṭebhi ca merusamebhị̣ | sarvaviśsisța

[Bhadracari-praṇidhāna]

[16] <9trisr> akṣobhya++++++++++ āryāvalokiteśvara-mahāsthāmaprāptaāryamaitreya-āryamañjuśrī-āryavajrapāṇi-āryasamantabhadraprabhṛtibhyo mahābuddha[bo]dhisattva+++++++++++van āryāvalokiteśvara tava hṛdayam

\footnotetext{
6 bhagavān] ac.; bhagavān sā ca sarvāvatī parșat sadevamānuṣāsuragandharvaś ca loko pc. 19 niṣaṇṇaku] pc.; nișaku ac. 23 mālyava++++++++++bhị̣] ac.; mālyavarebhi vādyavilepanachattravarebhị pc. $\mathbf{2 8}$ Seemingly not this folio follows. 29 -samanta-] pc.; -samantasamanta- $a c$.
} 
āvartayiṣyāmi | sarvakāmaprasādhakam | adhṛṣyaṃ sarvabhūtebhyai bhavamārgavināśanam | samyathedam | he bodhisattva priyabodhisattva mahābodhisattva he hale āryāvalokiteśvara maheśvara paramamaitracitta hitacitta mahākāruṇika kāmaṃgama | viyaṃgama viyati 2 mahāviyati 2 dhara 2 dhiri 2 dhuru 2 dharādhara 2 cala candrācala namas te 'stu oṃ hrīḥ sarvasattvābhayaprada hāhā hari 2 harivāhanodbhava bhavābhava bhavānagha turu 2 kuru 2 suru 2 muru 2 curu 2 suprasādasitāmalavimalamūrte he he bhagavan āryāvalokiteśvara maheśvara mahākāruṇika kṛ̣ṇājinadhara akșadhara kamaṇḍalu<9trisv>dhara dạ̣ḍadhara padmadhara pūtapavitrajațāmakuṭālamba pralamba cala 2 mala $2 \quad 10$ kala 2 kamala 2 cala 2 nala 2 dala 2 jala 2 hala 2 hili 2 hulu 2 halāhala halāhala he bodhisattva priyabodhisattva mahābodhisattva namas te 'stu hūm hūm kuru hṛdayam anusmara samayam anusmara jātim anusmara satyam anusmara buddhasatyam anusmara dharmasatyam anu[sma]ra samghasatyam anusmara | idaṃ ca me kāryaṃ kuru 2 bhūta 2 mahābhūta svāhā ||

eșa vidhih pratidinam prātar utthāya śucinā śucivastraprāvṛtena bhagavata āryāvalokiteśvarasya purato 'patitagomayena caturasraṃ [mạ̣ḍalakaṃ kṛtvā] ++++++++ trayodaśavārān uccārayitavyaḥ | tataḥ sarvavyādhīn apanayati | māraṃ copaśamayati | ekamanorathaṃ kṛtvā ṣaṇmāsenaivaṃ kurvato manorathaṃ ++++++++++ bhagavān avalokiteśvaraḥ | pañcānantaryakārī api sidhyet | yadi na sidhyet tadā aham eva pañcānantaryakārī syām | visaṃvādi

[Halāhala-hṛdaya]

[17] <10r> [namo bhagavatyai āryoṣnịṣa]vijayāyai || prathamat tāvan mantrī mukhaśaucādikaṃ kṛtvā sukhāsanopavișțaś caturbrahmavihārān bhāvayet | tadanantaram svahṛdy akārapariṇatam candramaṇḍalaṃ dhyātvā tadupari sitabhrūṃkāraṃ dṛșṭā tadvinirgataraśmisamūhair jagad avabhāsya purataḥ sarvabuddhabodhisattvān vicintya pūjāpāpadeśanādikam kuryāt | tataḥ oṃ śūnyatāsjñānavajrasvabhāvātmako 'ham | tatah punar api svahṛdindau yạ̣kārajaṃ viśvadalakamalaṃ dhyātvā | tadupari candrabimbamadhyagaṃ sitabhrūṃkāraṃ dṛṣtvā tatpariṇatām uṣnīṣavijayām | caityaguhāntasthāṃ sitavarṇāṃ trimukhāṃ trinetrām | așțabhujām | $\leq \leq \leq \leq$ sarvālaṃkārabhūṣitām | viśvadalakamalacandrasthām | baddhaparyañkām | prathamasitavadanām | dakṣiṇapītamukhām | vāmanīlamukhadaṃsțrāpuṭāvașțabdhoṣṭhām | dakṣiṇacaturbhujeṣu

6 cala] corr.; cale ms. 12 hūṃ hūṃ kuru] pc.; hūṃ ac. 22 Probably continued on 4r. 23 Seemingly not this folio follows. 34 -șțabdhoșțhām] $p c$.; -șțaboșțhām $a c$. 
viśvavajraraktāravindastha-amitābhajinaśaravaradahastām | vāmacaturbhujeșu <10v> dhanuḥtarjanīpāśa-abhayabhadraghațahastām | vairocanamukuṭinīm | divyavasanaparidhānottarīyāṃ nānālaṃkārabhūṣitām || sitaprabhāmālinīm paśyet | tasyā dakșiṇe lokeśvaro | vāme padmadhārī | dakșiṇe cāmarahastạ̣ | vāme vajrapāṇiḥ | kuvalayadalaśyāmaḥ | vāme kuvalayasthavajradhārī| dakșine 5 cāmarahastah | etau niṣaṇnau cintanīyau | tatah pūrvadakșiṇapaścimottareṣu | acala | țakkirāja | nīladaṇḍa | mahābalāḥ | sarve nīlā dvibhujā ekamukhās trinetrāḥ pratyālị̣̄hāḥ vyāghracarmāmbarāḥ | ūrdhvakeśāḥ | așțanāgābharaṇāḥ | viśvadalakamalasūryākrāntāḥ | vāme tarjanīpāśahastāḥ | dakṣiṇe khaḍgaan̉kuśanīladaṇḍavajrahastāḥ | bhāvanīyāḥ | upari śuddhāvā[sa | kāyikau] ++++++++ | pūrṇakumbhabhūtāmṛtaṃ pravarṣamāṇau | evaṃ saparivārāṃ bhagavatīṃ dhyātvānyā saṃkuryāt | oṃ śirasi āḥ kaṇṭhe | hūṃkāraṃ hṛdaye + <13r $>+++++++++$ pādayoḥ | tato mudrāṃ bandhayet | saṃpuṭāñjalim kṛtvā tarjanyau saṃkocya jyeșṭhāngușțhābhyāṃ sādhukāraṃ dattvā oṃkāratrayasahitāṃ dhāranīm e++++artya paścād vinā mudrayā āvartayet | oṃ svāhā || hṛdayamantraḥ | oṃ amṛtāyurdade svāhā || upahṛdayamantraḥ || oṃ amite amitodbhave amitavikrānte amitagātre amitagāmini | amitāyurdade gaganakīrtikare sarvakleśakșayaṃkarīye svāhā || iti mālāmantraḥ ||

Āryoṣnịịavijayā-sādhanaṃ samāptam || ||

[18] oṃ namo amṛtāya amṛtodbhavāya amṛtaṃ me kuru amṛtāya namo namạ̣ svāhā || oṃ amṛtakuṇḍali kha 2 khāhi 2 tișṭha 2 bandha 2 hana 2 daha 2 garja 2 kamya 2 visphoțāya 2 sarvavighnavināyakān mahāvajrakrodhamahādaṃștrotkațabhairavāya asimusalapaśupāśahastāya mahāgaṇapatijīvitāntarāya svāhā || ||

[Vasudhārā-dhāranị]

[19] <13v> namo buddhāya \|

athātaḥ saṃpravakṣyāmi prajñāpāramitodayam |

yayā bhāvitayā sarvavādinigrāhako bhavet |

dvibhujām ekavadanā sitavarṇām manoramām |

ardhacarcakeśāṃ ca ++jabimbusthitām |

padmaṃ dakṣiṇahaste tu raktavarṇaṃ vibhāvayet |

prajñāpāramitāṃ vāme vajraparyañkaṃ saṃsthitām |

sarvālaṃkārabhūṣitāṅīi bhāvayen nābhimaṇḍale |

aṃkāra++sambhūtāṃ paramānandakāriṇīm |

samayasattvaṃ niṣpādya jñānasattvaṃ vibhāvayet |

șaṇmāsābhyāsayogena prajñāpāramitau bhavet |

saptarātraprayogeṇa sarvaśā+++++ 
++jāpaprayogena saptaślokam dine dine karoti vā prayatnena śatagranthaṃ tu dhārayet | atra mantrapadāni bhavanti | oṃ picu 2 prajñāvardhani jvala 2 me ++++++++++++ | akākarudite anena mantreṇa saptābhimantritam ayācitamāranālaṃ șaṇmāsān pibet | prajñā bhavati medhāvī mahān iti |

Vajrasarasvatī-sādhanaṃ samāptam || ||

[20] <14r>kā gāthā || ||

namaḥ samantabuddhānām apratihataśāsanānām | oṃ kiṇi kiṇi tathāgatodbhave śānte varade uttamottame tathāgatodbhave hūṃ phaṭ ++++nayā dhāraṇyā dhāritayā āryagaṇụavyūhasūtraṃ dhāritaṃ bhavati || || namaḥ samantabuddhānām apratihataśāsanānāṃ oṃ dhuna dhuna hūṃ hūṃ phaṭ svāhā || +++++ṇyā dhāritayā āryasamādhirājasūtraṃ dhāritaṃ bhavati || || namaḥ samantabuddhānām apratihataśāsanānāṃ oṃ maṇidhari vajrinị hūṃ hūṃ phat ++++++ dhāriṇyā dhāritayā mahāpratisarā bhavati || || namo vajrasattvāya || koțākṣaḥ koțavaḥ koțah koțāvaś ca ka++++++++++++++++++++++++++ || etāni daśanāmāni vajrapāṇes trayaḥ pațhet tasya vajradharo rājā putravad varado bhaved dadāti [rājyaṃ]

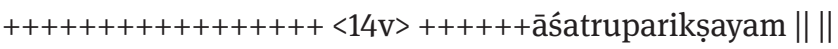
namah samantakāyavākcittavajrānām | oṃ uṣnịṣacakravarti sarvalaukika+++++++++++++++++++++++pena kenacit kṛtāni tāni sarvāṇi cchinda 2 bhinda 2 hana 2 daha 2 garja 2 kampa 2 vidhvaṃsaya 2 anekaśatasahasra+++++++++++++ttibhrū || || oṃ siddhih | lohaguṇụakarpalaikaṃ harìtavyāḥ palena cakarivadanarasasya bhakșaṇaṃ ca keśarājasya nīlāsingikā [tatraiva saptasapt]+++nenava | trayasaptāhaparatas tu śarkarāyalaikam dattvā ghṛtena saha sthāpayet | śeșaṃ ca punaḥ saṃskaranịiyaṃ tato māsakaikaṃ bhakṣayet | bhṛngārājarasapala+++tārasapala $1+++[$ sapala] 1 pānīyapala 1 ukāñjikapala 8 tilatailapala 1 ukṣadrakeśarājarasapala 2 etat sarvaṃ kṣayaṃ nìtvā tailașoḍaśapala |

[Unidentified text]

5 ayācitamāranālaṃ] corr.; ayācitāranālaṃ ms. 6 vajrasarasvatī-sādhanaṃ samāptam || ||] corr.; vajrasarasvarasvatī-sādhanaṃ samāptam \|\|$p c$., vajrasarasva ac. 7 Seemingly not this folio follows. 
[21] <15r>+++++++++samantaraśmipariśuddhe | sarvatathāgatahṛdayādhișṭhānādhișthite | mudre mudre mahāmudre mahāmudrāmantrapade svāhā ||

Āryoṣnịṣavijayā-nāma-dhāraṇī samāptā ||

[22] nama āryāșțamahābhayatāriṇyai || yasyāḥ smaraṇamātreṇa nașțam așțabhayānakam | tāṃ praṇamya pravakṣyāmi sādhanaṃ ca śiśo śṛ̣u | dhyātvā gaganamadhye tu tārām așțabhayāpahām | pūjāmanomayịm kṛtvā kuryāt pāpasya deśanām | punyānumodanāṃ paścād ātmapuṇyani ++nām | ātmabhāvaṃ tato dadyāt śaraṇāni tridhā punah karoty akaraṇaṃ paścāc chūnyatāyāṃ tv anantaram | sva++++taḥ pa $<15 \mathrm{v}>$ dmam așțadalavikāsitam | tanmadhye tāṃ vicintyaiva nīlābham utpalaṃ tatah | tasya madhye punar bījaṃ vahniraśmiprabhāsvaram | tena devīm samutpādya sarvālaṃkārabhūṣitām | savyato++m devīm vāmenutpalakarās tathā ekavaktram svabimbāṃ ca navayauvanasaṃsthitām | sugandhipuṣpakeśāṃ ca padmacandroparisthitām | ardhaparyañkam avașțabhya rakșayed bhuvanatrayam | așțadevyāntarāle ca bhāvayet tārarūpinīim | sphuranmantratayā yogī kṛtvā dhyānam anāvilaḥ | oṃ tāre tuttāre ture svāhā || oṃ oṃ svāhā | pūrve oṃ tā svāhā | dakṣiṇe oṃ ture svāhā | paścime oṃ tu svāhā | uttare oṃ ture svāhā | vahnyādau oṃ tā svāhā | oṃ re svāhā | oṃ tu svāhā | oṃ re svāhā | sarvāś caitāḥ sphuradrūpāḥ | yathā devī tathā parāḥ | oṃ [tāre]+++++++ccha svāhā| puṣpaṃ deyaṃ gandhanaivedyādikam utpalamudrayā nivedayatīti | kṛtvā sādhanam evedaṃ navadevīsamanvitam | hatvāșțabhayaṃ ca sarvaṃ karontu ni

[Așțamahābhayatārā-sādhana]

[23] $<19 \mathrm{r}>++++++++++++++++$

+++++++++++++nān |

dharmāśravaṇās tișthantu kalpakoṭyo hy acintakāḥ |

lāśapa+++++++++++++

1 Seemingly not this folio follows. 29 Continued on 7 r. 
+++++++++dvipadottamāḥ \|

na buddhā vijugupsante cittena malinī kṛtān |

maitracittāhite sattvāṃs tārayanti bhavārṇavāt |

ye+++sabuddhā ye 'tìtā ye 'py anāgatāḥ |

anuśikṣaṃ nahaṃ teșāṃ careyaṃ bodhicārikām ||

saṃpūrya pāramīprajñāṃ șaḍgatisattvamocakaḥ |

sākṣātkṛtvā hy abhijñaḥ ṣaț+++yaṃ bodhim uttamām ||

ajātān asamutpannān agrāhyāṃś cāpy anālayān |

asambhūtān avijñaptān varmān budhyeya śūnyakān ||

niḥsattvajīvavigatam yoṣapudgalavarjitā

budhyeya dharmanairātmam yathābuddham maharșibhị ||

ahammametivigataḥ sarvavastuṣv aniḥsțtah |

sarvasattvahitārthāya dadyā dānam amatsarī ||

anābhogena me bhogāḥ <19v> syur bhāvanām abhāvataḥ |

sarvabhāva-abhāvān me pūryatāṃ dānapāramiḥ ||

acchidraśîlaśîlena buddhaśîlasamanvitaḥ |

atanmayaiś ca śillair me pūryatāṃ śīlapāramiḥ ||

pṛthivyaptejasi tathā vāyudhātāv aniș̣taḥ |

akrodho dakṣatasyāśta pūryatāṃ kṣāntipāramị̣ ||

ārabdhavīryaḥ satatam dṛ̣̣hotsāho ma[hā]balaḥ |

balavān kāya+++++yaṃ vīryapāramị̣ ||

māyopamena ca tathā vajropamasamādhinā |

sūraṅgamasamādhye ca pūryatāṃ dhyānapāramiḥ ||

trivimokșamukhadvārai+ ++++++++

+++++++yā pūryatāṃ prajñāpāramih ||

tejasā sarvabuddhānāṃ prabhayā cāvabhāsayan |

vīryeṇa bodhisattvānām āśā++++++

+++++++++++++++++

+++pāramīyakām ākrāntā daśabhūmayah ||

ity Ārya-maitreyanāthasya ++++++++

[24] $<\mathrm{Xr}>+++++++++++++$ bhedatah $\|$

sattvānām āvaraṇaṃ tatpratipakṣo 'grayānasambhāṣā

sarvāntarāyadoṣaprahāṇam eṣạ̣̄ tayā bhavati ||

2 vijugupsante] corr.; vijupsante ms. 11 dharmanairātmaṃ] ac.; dharmanairātmam uttamacakrahitārthasarvadehināṃ $p c . \quad 31$ Continued from 1680.8.2.11v. 31 bhedataḥ] ac.; ne caritakaukṛtānyā bhedataḥ $p c$. 
tadyathā oṃ vajraprākā[rovajraprākāre vajracakradaṃsțrabhayānake] | amale vimale nirmale cale cule culuke culeke culu culu buddhe svāhā || yo granthato 'rthato vā gāthādvayadhāraṇīm prayuñjīt | sa hi daśavidham anu+++[bhate] sattvottamo dhīmān || kṛtsnāṃ ca dhātupuṣtịm prāmodyaṃ cottamaṃ maraṇakāle | janmaṃ ca yathābhikāmaṃ jātismaratāṃ ca sarvatra || 5 buddhaiś ca samavadhānaṃ tebhyaḥ śravaṇaṃ tathāśray++++[muktim saha] budhyādvayamukhatām āśu bodhiṃ ca || || kṣayaṃ hi gacchanti mahānidhānā rājāgnicaurodakavipralabdhāḥ | śrutaṃ nidhā[nahi tathāgatā]+++++[koṭībhi] ++++++++sya mūlaṃ sattvārthayuktasya ca bodhicittam | yad yoniśaś caiva vaivekacittam aparigrahạ̣ sarvasukhasya mūla $\mid+++++$

[Gāthādvaya-dhāraṇī]

[25] $<\mathrm{XV}>++++++++++++++++++++++++$ talapratipratișţ̣ite [sapta] +++++++++

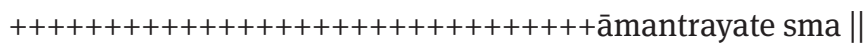

udgṛhṇīdhvaṃ yūyaṃ kulaputrā imāṃ șaṇmukhīṃ nāma dhāraṇi

sarvajaga +++++++++++++++++++++++++++++++ pratisamvidalakṣaṇaḥ yaś ca me kaścil laukikasampattisukhānubhavaḥ sa bhavatu sarvasattvasādhā+++++++++++++++++++++++++pratideśitam anuttarayā pratideśanayā | yāni ca me mārakarmāṇi tāni mā bhūvann aparijñatāny [anutta] +++++++++++++++[lamūlaṃ] laukikaṃ lokottaram vā tad bhavatv anuttarajñānaphalam | yā ca me vimuktiḥ sā bhavanta sarvasattvavimo[kṣāya |]

[Șaṇmukhī-nāma-dhāraṇī]

22 Continued on 9bisr. 


\subsection{Ms. Add.1680.8.2}

Extent: 2 folios, probably by different hands. Folios numbered online as 9 and 11 .

[1] <9r>hā || mūlamantraḥ || oṃ maṇivajre hūṃ | hṛdayaḥ || oṃ mạ̣idhari hūṃ phaṭ | upahṛdayam || ||

Ārya-mahāmaṇivipulavimānasupratișthitaguhyā-nāma-dhāraṇī samāptā || ||

[2] namo bhagavatyai āryavajraśṛnkhalāyai || oṃ namo bhagavati vajrāditye | vajraprākāre vajraśṛnkhale hūṃ hūṃ hūṃ mama saparivārasya sarvaśakrāna hana hana ghūrmāpaya ghūrmāpaya daha daha ādityạ̣ bandha hana hana vimuktapāpini vimuktapāpini bhasmāngi raktāngi bhūtaśmaśāne akațā+++++tādhaśiti vajrāditye vajraprakāre vajrașrnnkhale bandha bandha bhagavati maṇụalam pūrvadiśam bandha dakṣiṇadiśam bandha paścimadiśam bandha uttaradiśa ++++++++++++ daśadiśo bandha | daśagharāntaram bandha | saṃdhyāṃ bandha | trisaṃdhyāṃ bandha | visaṃdhyāṃ bandha | pāśam bandha | prāsāda+++<9v> prā++++++++++nāgāộhyạ̣ bandha | bhūtapretapiśācādīn bandha | brahmarākṣasādīn bandha | anyān api mama saparivārasyāhitaișiṇo dușțasa[ttvān bandh]+++prabhe jvaline jvaline mama saparivārasya sarvaśakraṃ saṃtāpaya saṃtāpaya pị̣aya pịḍaya vajraprākāre vajraśṛnkhale bandha bandha idam mạ̣ḍalaṃ sīghram āveśaya+++ya hana hana hūṃ phaṭ māraya svāhā || oṃ bhagavati vajraśrnnkhale dīptahutāśanāyai | kapilapingalalocanāyai | bhṛkuṭimukhāyai | mārjāracarmaprāvṛtāyai | caturdaṃșțākarālāyai | rudhirasampūrṇakapālāyai | bhagavati vajraśṛnkhale siddhavidyādharayakṣarākṣasapretapiśācakuṣmāṇḍagaṇasevite | mahāvidye | ekapādaṃ bandha | dvipādaṃ bandha | tripādaṃ bandha | catuṣpādaṃ bandha | ḍākinīm bandha | kațaḍākinīm bandha | sarvagrahān bandha | sarvaduṣṭān bandha |

tadyathā oṃ ca

[Unidentified text]

[3] <11r > +++++++++[li]ptaḥ kāmair anupalipto rūpaị̣ | asamsụșța ārūpyaiḥ | vimukto dụ̣khebhyạ̣ | vipramuktạ̣ skandhaị̣ | visamyukto

4 upahṛdayam] ac.; upahṛdayam | komale cūḍānāmadvitīyah suvarṇacūḍonāmatṛtīyovajracūḍonāma || $p c . \quad 5$ mahāmaṇi-] corr.; mahāmaṇe- ms. 9 Perhaps dittography? 28 Seemingly not this folio follows. 
bo++++++++++++++++++h | vimuktaḥ paridāhaih | parimuktas tṛṣnayā | toyād usttīrṇah | paripūrṇo jñāne | pratișṭhito 'tītānāgatapratyutpannānāṃ buddhānāṃ bhagava++++++++to nirvāṇe sthito bhūtakoṭā sthitaḥ sarvasattvollokanīyāyāṃ bhūmau | ime te kumāra tathāgatasya bhūtā buddhaguṇāḥ | ebhir buddhaguṇava[rṇaiḥ] samanvāgato bodhisattvo mahāsattva imaṃ samādhir māgamya anācchedyena pratibhānena tathāgatasyārhatạ̣ samyaksambuddhasya bhūtạ̣ buddhaguṇavarṇaṃ saṃprakāśayan no cārthato vyañjanataṃ ca paryādānaṃ gacchati | sarva cāsya vacanam buddhaparigṛhītam niścarati || buddhānusmṛti || ||

śubham astu sarvasattvānām |

[The Bhūtaguṇavarṇaprakāśanaparivarta of the Samādhirājasūtra]

[4] <11v >+++buddhāya \|

na divi bhuvi vā nāsmin loke na vaiśravaṇālaye na marubhavane na divye sthāne na dikṣu vidikṣu vā|

caratu vasudhāṃ sphītāṃ kṛtsnāṃ saparvatakānanāṃ puruṣavṛṣabhas tv atulyo ++++maṇaḥ kutaḥ || ekagāthā || || sarvabuddhān namasyāmi jinān apratipungalān | śarīrāṇi ca sarveșām sambuddhānām yaśasvinām || jayante yatra sambuddhā bodhim yatra ++++ ++++śivaṃ cakrạ̣ parinirvānty anāsravāḥ || yatra sthitāś can̉kramitā niṣaṇṇāś ca tathāgatāh | kalpitāḥ siṃhaśayyāś ca tān deśān praṇamāmy aham || ūrdhva [tirya]++++++++++++ +++rāśarīreșu stūpeșu praṇamāmy aham || pūrvottare diśobhāge tișțhate dvipadottamah | jino duṣprasaho nāma tenemai gātha bhāṣi+ +++++++++++ stuvanti tathāgatān |

kalpakoțīsahasrebhir na te gacchanti durgatim || caturgāthā || ||

buddhe dharme 'vajñām kausīdyam tuṣṭir alpa+++

[Gāthādvaya-dhāraṇī]

24 dușprasaho] corr.; dușprasabho ms. 29 Continued on 1680.8.1.Xr. 


\subsection{Ms Add.1680.8.3}

Extent: 29 folios. Two folios are numbered as 17. Folios 7-9, 11, 27, 28, 31 and 34 missing.

[1] <1r>++++++ svāhā | hūṃ svāhā | hrịḥ svāhā | dhūh svāhā | vāḥ svāhā | om ādityāya svāhā | oṃ somāya svāhā | oṃ dharaṇīsu+++++++++++++++++ svāhā | oṃ śukrāya svāhā | oṃ kṛ̣̣̣avarṇāya sanaiścarāya svāhā | oṃ rāhave svāhā | oṃ ketave svāhā | oṃ buddhāya svāhā | oṃ vajradhar+++++++++ | oṃ kumārāya svāhā | oṃ sarvagrahāṇām svāhā | oṃ sarvanakṣatrāṇām svāhā | oṃ sarvopadravāṇām svāhā | om bhagavatyai svāhā | oṃ dvādaśarāśī++++vidye hūṃ hūṃ phat phaṭ svāhā || ||

Ārya-grahamātṛkā-nāma-dhāraṇī || ||

[2] namaḥ sarvabuddhabodhisattvebhyaḥ || tadyathā oṃ dhupi dhupi kāyajvālani svāhā ||

Ārya-niyatakarmakṣayaṃkarī-nāma-dhāraṇī samāptā || ||

śrāvīryaśrīkṣunasya yad atra puṇyaṃ tad bhavatu sarvasattvānām ||

[3] <1v> +++tārāyai || evaṃ mayā śrutam ekasmi bhagavān sukhāvatyāṃ viharati sma | atha khalu bhagavān mahāśriyaṃ dṛștvā mañjuśriyam āryāvalokiteśvaram ca bodhisattvam mahāsattva[m e]tad avocat | yaḥ khalu punar mañjuśrīr mahāśriyo devatāyā nāmadvādaśakaṃ śroṣyati | bhikṣur vā bhikṣuṇi vā upāsako vā upāsikā vā | anyo vā yaḥ ka[ści]+++++++yiṣyati likhiṣyati likhāpayiṣyati | na tasya dāridryabhayaṃ bhaviṣyati | dāridryam prahāyaty ạ̣̄hyo bhavișyati | atha khalu +++++++++++++++bhāṣate sma | tadyathā om lakṣmịh śrīh padmamālinī dhanādhipatị gaurī mahāyašāḥ padmanetrī ka+++++++++++++prabhā $\mid$ mahā+++++mantrapadāni | +ini 2 glini 2 kāyaviśodhani vāgviśodhani manaḥsamśodhani | sisi sisi | nimi 2

$+++++++++++++++++$

[Mahāśrī-nāma-dhāraṇī]

4 Continued from 5v. 15 Note the donor's name. 
[4] <2r> ++++++++++li varāhamukhi mama sarvadușțapradușțānāṃ cakṣur mukham bandha bandha svāhā | oṃ mārīcyai svāhā | oṃ varale vadale vatgali varāli varāhamukhi++++ dușțapradușțānāṃ cakṣur mukhaṃ bandha bandha svāhā || idam avocad bhagavān āttamanās te ca bhikṣavas te ca bodhisattvā mahāsattvāḥ sā ca sarvāvatī parṣat ++++suragaruḍagandharvaś ca loko bhagavato bhāṣitam abhyanandann iti || ||

Ārya-mārīcīnāma-dhāraṇī samāptā || ||

[5] oṃ [praty]++++++ mahāśvetakapālahaste mahāśvetakapālamālādhari mahāyogeśvari aśītiyogasahasravināśani mama+++nacin mantratantrayantracūrṇakṛtaprayogādikaṃ $\leq \leq$ kṛtaṃ tat sarvān hana 2 daha 2 paca 2 chinda 2 bhinda 2 vajreṇa hūṃ phaț tasyaiva++++++++++++++++ $2 \mathrm{v}>$ hṛdayaṃ saptavārān āvartya bhagavatī pațhet || ||

[unidentified text]

[6] nama samantabhadrāya || namo bhagavate vajrajñānasāgararājāya tathāgatāyā[rhate samya]++++++++++++ sattvāya mahāsattvāya mahākārunikāya namo 'stu te buddhakoțībhāṣita ehy ehi samantabhadra eșa sarvāśāṃ paripūraya tvay+++++++++++++++kṛtā yena satyena buddho loke 'nuttarodharmo loke 'nuttarosamgho loke 'nuttarah tena satyena satyavacanena ehy ehi samantabhadra [pra]+++++++++++++ | om sara sara samantabhadra āgaccha 2 mā vilamba 2 yadi ŝighraṃ nāgacchayan tadā me vipaśyîśikhīviśvabhūkrakucchandakanaka++++++++++yaprabhūtayaḥ sarve bhādrakalpikā bodhisattvās tathāgatāś ca mayā visamvvāditā bhaveyuh | na tāvad aham anuttarāṃ samyaksambodhi+

[Ārya-samantabhadrapratijñ̄ā-nāma-dhāraṇī]

1 Seemingly not this folio follows. 15 samantabhadrāya] corr.; ntabhadrāya ms. 18 paripūraya] corr.; śaripūraya ms. 
[7] <3r> ++++++++ vadānavanāgayakṣarākṣasabhūtapretapiśācādīnām āveśane brahmāpramukhāṇāṃ ḍākinīnāṃ nigrahe dvipādacatuṣpādādīnāṃ bandhan++++++ākarṣaṇe anantapramukhāṇāṃ nāgānāṃ bandhane mahāgaṇapatipramukhāṇām anekagạ̣apatikoṭināṃ saṃyamane jvarāṇām ekāhik+++upaśāmane | mahāsainyānāṃ stambhane | sarvaduṣțānāṃ mohane | 5 yathā yathā prayujyate bhagavatī tathā tathā paṭhitasiddhā bhavati |

eșā Vajra++lā-nāma-mahāvidyā-sadārakṣā-paṭhitasiddhā-mahānuśamsāsaṃkṣepatạ̣ sarvamāravidhvaṃsanī samāptā || ||

[8] namo buddhāya || ṇamo +++ ṇamo dhammassa ṇamo saṃghassa tajjahā aț̣e vaț̣e ṇaț̣e kuṇațe țakke ṭhakke țharakke ḍarumati rurumati turumati $++++++++++<3 \mathrm{v}\rangle$ dupa dagga ṇamo sammasambuddhānāạ sidhyantu me mantrapadāḥ svāhā || imāṃ vidyām anantajātismaraṇahetuṃ mahāprabhāvāṃ saptapañcāśada[kṣarā] ++++++++++++++ bhayarakṣārtham prayuñjīt || || namo bhagavate ratnaśikhine tathāgatāyārhate samyaksambuddhāya | tadyathā om ratne 2 mahāratne ratnodbhave ratn+++++++samudgate svāhā || ārya-jātismarā-nāma-dhārạ̣ī anekānuśaṃsā dhārayitavyā || || namo ratnatrayāya || namo bha+++++++rājāya tathāgatāyārhate samyaksambuddhāya | tadyathā oṃ vajre 2 mahāvajre | sarvavyādhị̣ me hara 2 vajreṇa svāhā | hana 2 vajreṇa $++++++++++[$ svā] hā | paca 2 vajreṇa svāhā | kuṭa 2 vajreṇa svāhā | muñca 2 vajreṇa svāhā | cira 2 vajreṇa svāhā || idaṃ vajrottarāhṛdayaṃ saptavāraṃ parijapya

[Unidentified text]

[9] <4r>sabudhyeya | [yāvad apy] āgreṇa mātrighātakasyāpi pitrighātakasyāpi 25 stūpabhedakasyāpi saddharmabhedakasyāpi na pratigacchey+++++++++++ sedaś+++++++yāmina sarvāśāṃ paripūrayāmi namo 'stu te samantabhadrasya sarvavyasanaparimocakasya tadyathā oṃ dhuru dhuru svāhā +++++++++++ ru kuru svāhā || oṃ muru muru svāhā || oṃ curu curu svāhā || namo 'stu te buddhakoṭībhāṣite svāhā ||

1 Seemingly not this folio follows. 22 vajrena] $p c$; vajre $a c .25$ Continued from $2 \mathrm{v}$. 
asyopacārah | sadhātukacaitya++++++++ḥ | ekaviṃśativārāna ekaviṃśatidivasān āvartayet | samantabhadraṃ paśyati | yam icchati tạ̣ varaṃ dāsyati ||

Ārya-samantabhadrapratijñā-nāma-dhāraṇī samāptā || ||

[10] namas tārāyai || namo guṇākarāya | namaḥ samantagandhāya tathāgatāya | namo aparājitavikrāmiṇe tathāgatāya $|<4 \mathrm{v}\rangle$ namaḥ sarvaniv[araṇaviṣkam]bhiṇe 5 tathāgatāya | namaḥ śāntarājāya tathāgatāya | namaḥ candrottarāya tathāgatāya | namo 'bhayaṃkarāya bodhisattvāya mahāsattvāya ++++++++ tadyathā oṃ dhare dharādhare | dharaṇi | rạ̣agotre | abhayakalpe | kalpavigate | anantakalpe | amṛtakalpe | hutāśane | anantamukhe | +++++++++ | oṃ bhūḥ svāhā|

ime kulaputra dhāraṇīmantrapadā gañgānadīvālukāsamai buddhair bhagavadbhi bhāṣitā | adhișthitā | anumodi+++++++ sattvānām arthāya | yaḥ kaścit kulaputra imāṃ dhāraṇị̣̄ dhārayati | so 'șțebhyo mahābhayebhyaḥ samatikrā+ bhavati |+++++kabhayād anantāt tiryagyonibhayāt | anantāt yamalokabhayāt | anantā pretabhayāt | anantā+++++++++++ $<5 r>+\mid$ anantān sattvān maraṇabhayāt | anantā durbhikṣabhayāt | daśasu dikṣu buddhā bhagavantạ̣ | samanvāharanti | avikṣipta svakālaṃ kariṣyati | buddhānāṃ sammukham upapadya[te] | akṣayakāyitāṃś ca pratilabhate | nirvāṇakāyatāṃ ca pratilabhate | nama sarvavidye sidhyatu me mantrapadā svāhā ||

Așțamahābhayatāraṇī-nāma-dhāraṇī samāptā || ||

[11] nama āryāvalokiteśvarāya bodhisattvāya mahāsattvāya mahākāruṇikāya | tadyathā oṃ śvete śvete mahāśvete hṛdayạ̣ me praviśāhi | īpsitaṃ me vijānāhi | hili mili svāhā || bhagavato avalokiteśvarasya mantroccāraṇamātreṇaiva | sahasrajanmopacitaṃ pāpaṃ parikṣayaṃ gacchati saptajātikoṭị̣ jātismaro bhavati ॥

Ārya-jātismarā-nāma-dhāraṇī samāptā || ||

8 raṇagotre] $p c$; rạ̣e gotre $a c$. 
[12] namo ratnatrayāya || namo buddhāya | namo dharmā<5v>ya namaḥ saṃghāya | namo vajradharāya namaḥ padmadharāya namạ̣ kumārāya | namaḥ sarvagrahāṇāṃ sarvāśāparipūrakāṇāṃ namo nakṣatrāṇāṃ namo dvādaśarāśīnāṃ namaḥ sarvopadravāṇām tadyathā om buddhe buddhe vajre 2 padme 2 sara 2 prasara 2 smara 2 krīḍa 2 krị̣̄aya 2 mara 2 māraya 2 mardaya 2 ghātaya 2 mama sarvasattvānāṃ ca sa++++ cchinda 2 bhinda 2 sarvavighnān kuru 2 mama kāryaṃ kṣapaya 2 sarvapāpāni me śānte 2 dānte 2 dāmaya 2 dāpaya 2 drutạ̣ darśayātmānaṃ bhagavati rakṣa 2 māṃ [sarva]sattvāṃś ca sarvagrahanakṣatrapị̣āṃ nivāraya bhagavati śreyaḥ kuru mahāmāye prasādhaya sarvaduṣṭān nāśaya sarvapāpāni me vajre 2 caṇde 2 caṇḍini +++++++++2 muru 2 muya 2 muñca 2 havāhave bhavābhave ugre ugratare pūraya 2 bhagavati manoratham mama sarvasattvānāṃ ca sarvatathāgatādhișțhānādhișțita

[Grahamātṛkā-dhāraṇī]

[13] <6r>ḍeti | nikuruḍā | nikuruḍeti | puruḍā | puruḍeti | nipuruḍā | nipuruḍeti

| phuṭurahe | sphuṭu țuṭuṇḍarahe | nāgarahe | nāgațuṭuṇụarahe | sarparahe | sarpațuṭuṇ̣arahe | ++ | acchale | kalavișe | śîte | śītavattāle | hale | halale | tụ̣de | tutuṇḍe | taṇḍi taṇdị | taṭa | tața | sphoța | sphoța | sphoṭatta viṣam svāhā | iti hi bhikṣa++[ñgu]lyā mahāvidyāyāḥ sarvadevāsuranāgayakṣabhūtasamāgame bhāṣitam | lapitam udīritam | pravyāhṛtam | sarvaṃ tattathā | avitathā | nānyathā | bhūtaṃ ++++++vadaviparītam | aviparyastam | buddhasatyam anusmara | dharmasatyam anusmara | saṃghasatyam anusmara | satyavādinām satyam anusmara | anena sa+++++++ idaṃ viṣam aviṣam bhavatu | dātāraṃ gacchatu | daṃșțāraṃ gacchatu | agniṃ gacchatu | kupyaṃ gacchatu | jalaṃ gacchatu | stambham gacchatu | śāntim gacchatu | svastyayanaṃ gacchatu $<6 \mathrm{v}>$ nmamanā++hi tat sarva+śya te vișam | tadyathā oṃ ili mitte | tili mitte | ili tili mitte | dumbe | dumbālī e | dusme dusmālī e | tarke tarkaraṇe | marme | marmaraṇe | kaśmīre | kaśmīra+++++++agha naghane ili ilī e | mili milī e | akkhā i e | appā i e | śvete | śvetatuṇde ananurakte svāhā $\|$ iyam asmākam bhikṣave ++ | [sarvaśvetāsu]dakṣiṇā | ya imāṃ vidyāṃ sakṛt śṛ̣oti | sa saptavarṣāṇi ahinā na daśyate | na cāsya kāye viṣaṃ saṃkramiṣyati | ya imāṃ vidyāṃ bhi[kṣu] vā dhārayiṣyati | sa yāvajjīvam ahinā na daśyate | na cāsya kāye viṣaṃ krāmati | yaś cainam ahir daṃśyeta | tasya saptadhā sphuṭen

12 ugratare] corr.; ugrataye ms. 14 Continued on 1r. 15 Seemingly not this folio follows. 22 anusmara] corr.; anusma ms. 
mūrdhā arjakasyeva mañjarī | imāni ca mantrapadāni sarpasya purato na vaktavyāni | yat kāraṇaṃ sarpo griyate |

tadyathā | illā | cillā | cakko | vakko | koḍā | koḍeti | moḍā | moḍeti | kuru+++

[Jāṅgulī-mahāvidyā]

[14] <10r>larala bhagavati ehi ehi āgaccha āgaccha | idam karma kuru kuru rakṣa rakṣa māṃ saparivāraṃ sarvasattvāṃś ca svāhā || ye mama saparivārasyāhitaiṣiṇas teșām śarīram praviśya hṛdaya gṛhṇa gṛhṇa śiro gṛhṇa gṛhṇa grīvām gṛhṇa gṛhṇa kāyam gṛhṇa gṛhṇa hastam gṛhṇa gṛhṇa pādạ̣ gṛhṇa gṛhṇa kampaya kampaya kampāpaya kampāpaya gṛṇāpaya grhṇāpaya bhrāmaya bhrāmaya ghūrmaya ghūrmaya ghūrmāpaya ghūrmāpaya 10 maṇdalamadhye vikurvaya vikurvaya tața tața mața mața moțaya moțaya sphoțaya sphoțaya mama saparivārasya sarvaśakrāṇāṃ marmāṇi nikṛntaya nikṛntaya hṛdayam bhinda bhinda cchinda cchinda hana hana paca paca dara dara matha matha pramatha pramatha cala cala māraya māraya gṛhṇa gṛhṇa bandha bandha hasa hasa hisi hisi cara cara hūṃ hūm kị̣ cirāyasi devanāgayakṣarākṣasagandharvāsurakiṃnaramahora<10v>gamanuṣyāmanuṣyasarvabhūtapretapiśācaḍākinīnām āveśaya āveśaya bhagavati vajrapāśenākaț̣aya ākațțaya bhrāmaya bhrāmaya samayam anusmara hūṃ hūṃ hā hā hī hī kiṃ cirāyasi mānuṣaśarīraṃ praviśya nivasasi nivasasi oṃ hạ̣ hị̣ hūṃ tața tața rakṣa rakṣa māṃ saparivāraṃ svāhā || namo bhagavatyai rakta++yai | mahācaṇḍavajrapāṇaye mama saparivārasya śatrūṇāṃ sarvagātrāṇi saṃkocaya saṃkocaya bhañjaya bhañjaya moṭaya moțaya bhagavati vajraśṛnikhale vajrapāśenākațtaya ākaț̣aya ākarṣaya ākarșaya cakṣur bandha 2 śiro bandha 2 sarvagātrāṇi bandha bandha mardaya mardaya sarvāṃs tān māraya māraya puṣpaṃ dhūpaṃ gandhaṃ baliṃ gṛhṇa svāhā || eșā vidyā prayoktavyā nirviṣịkaraṇai pātrāveśane maṇḍalabandhane vaśīkaraṇe ākarṣaṇe nivyutpāṭane māraṇe vidveṣaṇe ++

[Unidentified text]

4 Probably continued on 17 r. 5 Seemingly not this folio follows. 
[15] <12r>+dhimardayet | tato gaṇḍapiṭakavātalatāśoṣagulmaśūlādīni | caturottaravyādhiśatāni manasi kartavyāni | tatạ̣ sarvavyādhayạ̣ praṇaśyanti | satatajāpena va+[pā]ṇiguhyādhipatisuto rakṣāṃ karoti ||

Ārya-vajrottarā-nāma-dhāraṇī samāptā || ||

[16] namo ratnatrayāya || namas tryadhvagatānāṃ tathāgatānāṃ va+++++[bha] 5 m akṣobhyam cāryāmitābham ca vande 'ham avalokitam | tadyathā sūkṣme sūkṣme || sānte śānte || dānte dānte nirākule | yaśoteja | teje+++++++++ sarvabuddhādhișţhānānumodite svāhā || anayā mṛtapiṇụạ̣ saptābhimantritaṃ kārayet | oṃ araje viraje svāhā | rajebhimantri+++++++++++++++vajragarbha svāhā | mudrābhimantraṇam | om 10 supratișṭhite stūpe svāhā | sthānābhimantraṇam | tata imāṃ dhāraṇiṃ paṭhitvā caityakarma ka

[Koṇḍ̄ā-nāma-dhāraṇī-caityakaraṇa-vidhi]

[17] $<12 \mathrm{v}>+++++++++++++++++++$ sarvatathāgatānām | oṃ mahācintāmaṇijvalana ++++++++++++++++++++++++++++++++++++++++++++++++++++++

mahāsamaye tiṣtha 2 mahā +++++++++++++++++++++++++++++++++++

+++++++++++++++++++++++++++++++++++++++++++++++++++

$+++++++++++++++++++++++++++++++++++\mid$ ākarṣaya 2 ākațțaya

2 tara 2 saṃtara $2++++++++++++++++++++++++++++++++++2$

saṃ́odhani 2 viśodhani 2 hara hara mama pāpaṃ sarvatathāgata-

kula+++++++++++++++++ $<13 \mathrm{r}>+++++++++++++++++++++++$ vimale | kavacita $++\mid$ vikasitapadme $|++++++|$ pūraṇi $\mid$ oṃ sarvatathāgatoṣnịisavilokite svāhā $\mid+++++++++++++++++++++++++++$ svāhā $\mid$ om ++ vile $\mid$ +++++++++++++++++daṇde svāhā $\mid++++++++$ svāhā $\mid$ om ++++++++++++++

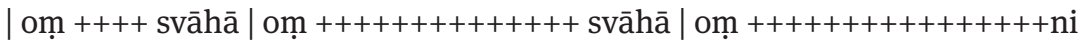
svāhā | oṃ sarvatathāgatamahādhișṭhānādhișțite svāhā | +++++++++++++++++++ namah $\mid+++++++++++++++++++$ dhātugarbha samtara $2+++++++++++++++++++++++++++++++++++\langle 13 \mathrm{~V}\rangle$ ++++++++++++++nāma-dhāraṇī samāptāh || ||

[Cintāmaṇi-nāma-dhāraṇī]

1 Seemingly not this folio follows. 
[18] namo bhagavate vipulavadanakāñcanotkṣiptaprabhāsaketumūrdhatathāgatāya namah śākyamunaye [tathāgatāyārhate samyaksambu]ddhāya | tadyathā bodhi 2 sarvatathāgatagocare dhara 2 hara 2 mahābodhipratișțhite | mahābodhicittadhare culu 2 sahasrara[śmi]saṃcodite sarvatathāgatābhiṣikte guṇi guṇavati | buddhaguṇāvabhāse

| gaganatalapratișțhite sarvatathāgatādhi[ș̣hi]te svāhā | nabhastale śama 2 praśama 2 sarvapāpapraśamane | sarvapāpaviśodhane hulu 2 mahābodhimārgasamprasthite | sarvata[thāgatapratișthi]te śuddhe svāhā | hṛdayam | kuru 2 jayamūle svāhā | upahṛdayam | yah kaścid bhikṣur vā | bhikṣuṇī vā | upāsako vā upāsikā vā | anyo vā | yaḥ śrāddhaḥ kulaputro vā | kuladuhitā vā | imām dhāraṇị̣ likhitvā ekam api caityaṃ kariṣyati tasya caityasyābhyantare | imāṃ dhāraṇiṃ sthāpayiṣyati | tenaikacai<14r>tyaṃ kṛtvā lakṣacaityāḥ kṛtā bhavanti | tena sarvacaityāḥ pūjitā bhavanti | divyai gandhadhūpair mālyavilepanacūrṇacīvaracchattradhvajapatākābhiś ca | na kevalaṃ caityāḥ pūjitā bhava++ buddharatnaṃ pūjitaṃ bhavati | evaṃ dharmaratnam pūjitam bhavati | evaṃ saṃgharatnam pūjitam bhavati | vividhair upakaranaị̣ pūjitā bhavanti | evaṃ mayānanda saṃ[kṣi] ptena deśitaṃ mandapunyānām aśraddhānāṃ mithyādṛ̦țikānāṃ vaimatikānāṃ naimittikānām ānantaryakāriṇām alpāyuṣkāṇāṃ narakapretatiryagyama++[parāyaṇānāṃ] sattvānām arthāya | s iyaṃ dhāraṇī bhāṣitā || ||

Ārya-lakṣa-nāma-dhāraṇī samāptā || ||

[19] nama āryāva[lokiteśvarāya bodhisattvāya ma]hāsattvāya mahākāruṇikāya || tadyathā munidaṇ̣̣e muniprabhāsvare svāhā || eșa bhagavata āryāva $\leq$ lokiteśvara $<14 \mathrm{v}>+++++++++++++++$ mātram ādāya | așțaśatābhimantritaṃ kṛtvā bhakṣayen naraḥ | prathame divase granthasahasraṃ dhārayet | pațhitamātram ca dine dine sa++++++++++divase śrutidharo bhavati |

Dṛșțapratyayah-śrutidharā-nāma-dhāraṇī samāptā || ||

7 buddhaguṇāvabhāse | gaganatalapratișțhite sarvatathāgatādhi[șțhi corr.]te svāhā | nabhastale śama 2 praśama 2 sarvapāpapraśamane] $p c$; buddhaguṇāvapraśamane $a c$. 
[20] om padmodbhavaḥ | padmahastah padma++ padma[nāya]kaḥ | padmalocanaḥ | padmāgrīr lokeśvaro guṇeśvarah || āryāvalokiteśvarasyaitāny așțanāmāni prātar utthāya yaḥ pa++++ jātau jātismaro bhavati rājā ca bhavati cakravartī || ||

namaś cundāyai || namaḥ saptānāṃ samyaksambuddakoṭīnāṃ

tadyathā oṃ cale cule+++++vīrye 'pratihataśāsane mahābalaparākrame asimusalaparaśupāśagṛhītahaste mahākrodhe | krodheśvari | ugrarūpiṇi | $<15$ r $>$ anantamu[khi sa]hasrabhuja | apratihate | ajite | aparājite | amoghe | durdame | sahasrākṣi | sarvatathāgatādhișțhite | sarvadevatānāṃ vandite | pūjite | prasādhi+ vajragho[șe] | vajre | vajrāvahe | vajrāyudhe | vajrakātyāyani | vajronmīlitākṣi | akṣaye | aghore | ghorarūpiṇi vikṛtadaśane | vajravaidūryālaṃkṛtaśarīre || oṃ bhagavati cunde cuṃ cuṃ druṃ druṃ truṃ truṃ mruṃ mruṃ sruṃ sruṃ ruṃ ruṃ gṛhna 2 gṛhnāpaya 2 āveśaya 2 hara 2 sara 2 māra 2 bhañja 2 hana 2 daha 2 paca 2 gṛhna 2 idam duṣțagraham [jvaram] ekāhikaṃ dvyāhikam | tryāhikaṃ cāturthakaṃ saptāhikaṃ māsikam | ardhamāsikaṃ sāmvatsarikaṃ nityajvaraṃ viṣamajvaram | mauhūrtikam | vātikaṃ paittikam | śleṣmikaṃ sāṃnipātikam | graham | bhūtam | vetāọam | yakṣaṃ rākṣasaṃ kumbhāṇḍam yonijam sthāvaram jaṅgamaṃ ye mām himsanti duṣtāis tān sarvān sādhaya 2 mardaya $2<15 \mathrm{v}>$ tāpaya 2 śoṣaya 2 ucchādaya 2 hana 2 vajreṇa sara 2 dạ̣ḍena māra 2 khaḍgena hūm 2 cūm 2 hrūṃ 2 oṃ cale cule cunde mama kṛte sarvaduṣṭasattvān sādhaya sādhaya svāhā || ||

Śrī-vairocana++nasampattidāyikā ārya-cundā-dhāraṇī-sarvatathāgatahṛdayā samāptā || ||

[21] namo ratnatrayāya || namo 'tītānāgatapratyutpannānām | sarvatathāgatānāṃ samyaksambuddhānāṃ namo 'mitābhāya tathāgatāyārhate samyaksambuddhāya | tadyathā om śodhi | medhi | dhi+++++ve | buddhavati | buddhāvabhāsite | sarvadharmolkāprajvālini | buddhi buddhi | mahābuddhi | mahāvege | vīre | vegavati | garuḍavegavati | indravajra[vega]++ | buddhavilokite | muni muni | namo mahāmuni | phaṭ | namo buddhabalena | sarvayakṣarākṣasapiśācakumbhāṇ̣̣apūtanakațapūtanasarva[graha]+<16r> ++++++++vīraka gṛhna 2 grasa grasa | māra 2 bhañja 2 daha 2 paca 2 matha 2 sarvabuddhānubalena | nāśaya | vināśaya | bhinda 2 chinda 2 kuru 2 muru 2 vidrāpaya 2 sarvayakṣarākṣasapiśācādīn manuṣyān bandha 2 saṃkoca vikoca | sphoțaya 2 garja 2 tarja 2 hana 2 mama śatrūn sarvamantrān | sarvaprayogān vihana 2 sarvarogān rakṣa rakṣa māṃ saparivāram sarvasattvāṃś ca sarvabhayopadravopasargopāyāsebhyaḥ svāhā || 
śirobandhanaḥ kṛtena sarvayakṣarākṣasapiśācādayo yojanasahasrāt prapalāyante | ekavāram abhyudāhṛtena saparivārasya rakṣāṃ kurute | yojanasahasre sthitasyāpi paṭitamātreṇa sarvaśatrūn vyāghrabhallūkān bandhayati | sarvajanasya priyo bhavati | dine 2 śatavārān uccārayet | ślokaśatam gṛhnāti | añjanam abhimantritam kṛtvā akṣiṇy añjayet | kro<16v>dhābhibhūtāh prasīdanti | dvilakṣajāpena sarvakleșāḥ prahịnā bhavanti | dhāraṇamātreṇa jātismaro bhavati | tailam ekaviṃśativārān parijapya śirasi mrakṣayet | śirorogabhagaṃdaram apasmāraviṣam ca nāśayati | marīcagulikā ekaviṃśativārān parijapya mukhe prakṣipya rājakule praviśet | yam icchati tạ̣ labhate yeșā samīhitārthaṃ sampādayati || ||

Ārya-hemāngāā-nāma-dhāraṇī samāptā || ||

[22] namo bhagavate akṣobhyāya tathāgatāyārhate sa[myaksam]buddhāya || tadyathā oṃ hūm kekani kakani | vākani vākani | rocani rocani | troțani | troṭani | saṃtrāsani | saṃtrā++++++++ 2 pratihana 2 sarvakarmaparamparāni me svāhā ||

ya imāṃ dhāraṇīm antasaḥ kuḍye likhitām api paśyet | tasya pañcānantaryāṇi parikșayam

\section{[Unidentified text]}

[23] <17r> | bhūmyāṃ nipatanta vi[șaṃ] svāhā | idam avocad bhagavān ānandas te ca bhikṣavaḥ sā ca sarvāvatī parṣat sadevamānuṣāsuragaruḍagandharvakiṃnaramahoragayakṣanāgaparṣad bhāṣitam abhyanandann iti ||

Ārya-jāngulī-mahāvidyā samāptā || ||

[24] oṃ jāñguli < sarvaviṣapraśamani phụ̣ svāhā | japamantraḥ | kalpoktakrameṇa paro hṛdayamantrah om asijihve śūlajihve vajrakāye grasa grasa jvala jvala mahājvāle mahāyogeśvari hūṃ hūṃ phaṭ phaṭ svāhā || || nama āryajāṅgulyāyai || atha bhagavatyā hṛdayaṃ vyākhyāsyāmaḥ || oṃ asijihve | śūlajihve | vajrakāye | grasa grasa | jvala jvala | mahājvāle | mahāyogeśvari hūṃ hūṃ phaṭ phaṭ svāhā || daśasahasrajāpāt sarvavișakarmasamartho bhavati | japaś cānena vidhinā kartavyaḥ | triṣkālasnāyī

2 abhyudāhṛtena] pc.; abhyudāhṛtāna ac. 9 -vārān] corr.; -vān ms. 19 Probably continued from 6v. 26 āryajāngulyāyai] corr.; āryānguulyāyai ms. 
madyamāṃsavasāpalāṇḍutailalavaṇavi<17v>varjitaḥ | triṣkālaṃ ca japet | yāvad daśasahasrāṇi tataḥ siddho bhavati | paścāt karmāṇi kārayet | anena vinyāsena prathamaṃ tāvan mantrī ātmānam īdṛśam cintayet | kumāryākārām haritavarṇāṃ saptaphaṭirājitamūrdhajām caturbhujām | ekahastena triśūlam | 5 dvitīyena mayūrapiccham | tṛtīyena sarpam caturthena prasāritābhayam | [sa]rvāngena nūpuramekhalāvalayakuṇụalādīn | sarpākārān cintayet | ekaikasmād romavivarād agnijvālām samantā niṣkāsamānāṃ vicintayet | evam ā+nikalpayet | ahaṃ tāvad devatā tatạ̣ sarpadașțakaṃ purataḥ sthāpya tāmrādibhājane udakaṃ pratișțhāpya | anayā vidyāyā saptavārābhimantritạ̣ saptavārān śiraḥprabhṛti+++yet punaḥ | etena nirviṣo bhavati | calaṃ ca viṣaṃ yaṃ yam evāngaṃ mūrchati tasmin tasmin mṛttikayā sakṛjjaptayā dhāraṇībandhaṃ valayayogena kārayet |

[Ārya-jāṅgulyā bhagavatyāḥ kalpaḥ]

[25] <17bisr>+nti | maraṇakāle ca akṣobhyas tathāgataḥ puratah sthitvaivaṃ cāviśati | āgaccha kulaputra matsakāśam iti || ||

Āryākṣobhyā-nāma-dhāraṇī samāptā || ||

[26] +++āya || namo bhagavate vajrottararājāya tathāgatāya samyaksambuddhāya \|

tadyathā oṃ vajre 2 mahāvajre | sarvavyādhị̣ me hara 2 vajreṇa svāhā || hana 2 ++ra $2+++$ svāhā | daha 2 vajreṇa svāhā | paca 2 vajreṇa svāhā | kuṭa 2 vajreṇa 20 svāhā | muñca 2 vajreṇa svāhā | vira 2 vajreṇa svāhā || idam vajrottarā ++++++++++++++++ mardayet | tato gaṇdapițakavātalatā | śoṣa | gulmaśūlādīni caturottaravyādhiśatāni manasi kartavyā ++++++++++++++ | satatajāpena vajrapāṇir guhyakādhipatisuto rakṣām karoti |

1 -vasā-] corr.; -vasona- ms. 6 -mekhalā-] corr.; -mekhā- ms. 9 pratișțhāpya] corr.; prakșișthāpya ms. 14 Seemingly not this folio follows. 
[27] <17bisv >+++++++++++++++++++++ bodhisattvāya mahāsattvāya mahākārunikāya|

tadyathā | oṃ cakravarti cintāmaṇi mahāpadme ruru tiștha jvālākarṣaya hūṃ $+++++$

+++++++nāma-dhāraṇī samāptā || ||

[Unidentified text]

[28] namaḥ sarvatathāgatānām | nama āryāvalokiteśvarasya bodhisattvasya mahāsattvasya ++++++moghapāśa mahādānapāramitā paripūraya | dara 2 vividhavicitrasattvāya bhogasarvatathāgatamahādāna+++++++++ | tara 2 tāraya 2 mahāpadmapāni hūṃ phaṭ svāhā ||

yat kiṃcid dīyate dānam | saptavān parijapya dātavyam || taddānam akṣayaṃ bhavate || namo ratnatrayāya || namas tryadhvagatānāṃ tathāgatānāṃ vande | ratnatrayaśubham akṣobhyaṃ cāryāmitābhaṃ ca vande 'ham avalokitam || tadyathā | sūkṣme | sūkșme | śānte | śā<18r>[nte | dānte dānte nirākule] | yaśoteje | tejovati | tejośuddhe | viśuddhe | sarvabuddhādhișțhānānumodite svāhā || anayāmṛtapiṇụaṃ saptābhimantritaṃ kārayet | oṃ [araje vira]++hā || rajebhimantraṇam | oṃ vajrāyuddhe svāhā || viśvābhimantraṇam | oṃ vajragarbha svāhā || mudrābhimantraṇam | oṃ supratișțhitastūpe svāhā || sthānābhimantraṇam | ta++māṃ dhāraṇịm paṭhitvā caityakarma kartavyam || ||

Koṇụā-nāma-dhāraṇī-caityakaraṇa-vidhị̣ samāptā || ||

[29] namo bhagavatyai āryamahādhāriṇyai + evaṃ mayā śrutam ekasmin samaye bhagavān śrāvastyāṃ viharati sma | jetavane anāthapiṇ̣adasyārāme mahatā bhikṣusaṃghena +++++++++++++++++taị̣ | atha khalv āyuṣmān ānandaḥ sāketake varșoṣitaḥ pātracivaram ādāya yena bhagavān tenopasaṃkrānta upasaṃkramya bhaga $<18 \mathrm{v}>+++++++++++++$ ekānte 'sthād ekāntasthitam āyuṣmantam ānandaṃ bhagavan etad avocat | udg̣̣hṇa tvam ānanda imāni mahādhāraṇimmantrapadāni sarvasattvānām a[rthāya] hitāya sukhāya dhāraya | grāhaya | vācaya | manasi kuru | paryavāpnuhi | tat kasya hetoḥ | durlabhā hy ānanda mahādhāranīmantrapadāḥ | durlabhas tathāgatānā++ samyaksambuddhānāṃ loke prādurbhāvaḥ | tadyathā| audumbarapuṣpasamam | yaḥ kaścid ānanda kulaputrā vā kuladihitā vā | imāṃ mahādhāraṇīmantrapadān dhā[rayi]ṣyati | vācayiṣyati | grāhayiṣyati | manasi kariṣyati | paryavāpsyati | nāsau śastreṇa kālaṃ kariṣyati | na viṣeṇa 
nāgninā kālaṃ kariṣyati | [na cā]sya rājabhayaṃ bhaviṣyati | na cāsya devāsuragaruḍakiṃnaramahoragayakṣarākṣasapretapiśācabhūtakumbhāṇ̣̣apūtanakațapūtanalūtāpasmāra-unmādakṛtyakarma<19r>+++++ostārakagraho vā bhavișyati | na cāsya jvarā vā | ekāhikā | dvyāhikā | tryāhikā | cāturthakā | sāṃnipātikā | nityajvarā | viṣamajvarā vā bhaviṣyanti | na ++++++ vā | mūlakarmā vā bhavișyati || samyyathīdam | bale mahābale | jvale | mahājvale | jvalite | ḍakke mukke | sampade | mahāsampade | tapane | mahā+++ svāhā | ime khalv ānanda mahādhāraṇīmantrapadāḥ saptasaptatibhị̣ | samyaksambuddhakoțībhir bhāṣitāḥ | mayāpy etarhi bhāṣitāḥ | yaḥ kaści+++ kulaputrā vā kuladuhitā vā | imāṃ mahādhāraṇimmantrapadāni dhārayiṣyati | vācayișyati | grāhayiṣyati | manasikariṣyati | parya+++++++++++++tisvaro bhaviṣyati | na cāsya bodhicittam vimuñcayiṣyati | samyyyathedam | aṇde maṇḍe | kṣame | mahākṣame | varado | anado | kule | $<19 \mathrm{v}>++++++++++++++$ svāhā $\|$

ime khalv ānanda mahādhāraṇīmantrapadāh | așțāsiītibhị̣ samyaksambuddhakoțībhir bhāṣitāh | mayāpy etarhi bhāṣitā |++++++++ kulaputrā vā kuladuhitā vā imāṃ dhāraṇīmantrapadāni dhārayiṣyati | grāhayișyati | vācayișyati | manasikarișyati | ya ++++ ti | sa caturdaśajāti jātismaro bhaviṣyati | na cāsya bodhicitta vimuñcayiṣyati | saṃyathīdam | ațte | vațe | țhakke | țharakke | țake | vare va++++kosi | mahākosi | ili mili raurave | mahāraurave timi | bhūtamgame | mahābhūtaṃgame | parāyaṇe | dyasi | mahamati | dyasi svāhā | ime kha[lv ānanda mahā]dhāraṇīmantrapadāni navanavatibhị̣ samyaksambuddhaị̣ koțîbhir bhāṣitā | mayāpy etarhi bhāṣitā | yaḥ kaścid ānanda kulaputro vā kuladihutā vā | <20r> imāṃ dhāraṇīmantrapadāni dhārayiṣyati | vācayiṣyati | grāhayiṣyati | manasi kariṣyati | paryavāpsati | sa ekaviṃśatijāti jātismaro bhavișyati | na cāsya +++[cittaṃ] vimuñcayiṣyati | tadyathā | akkile | vakkile | rule | auhani | mohani | śumbhani | jambhani | svāhā ||

yaś cemāny ānanda mahādhāraṇīma[ntrapadāny] atikramet | devo vā | nāgo vā | asuro vā | garuḍo vā | kiṃnaro vā | mahorago vā | yakṣo vā | rākṣaso vā | kumbhāṇḍo vā | pūtano [vā kaṭapūtano] vā | bhūto vā | apasmāro vā | manuṣyo vā | amanuṣyo vā | yo vā | so vā | tasya dhṛtarāșțro rājā taptenāyomayena ca +++++++ [va]jrapāṇiś ca mahāyakṣasenāpatir cakreṇādīptena pradīptena saptajvalitena | ekajvālībhūtena | praharet | śakro devānā<20v>++++++++++++[late]na | ekajvālībhūtena praharet | na cāsyāḍakavatyāṃ rājadhānyāṃ pātrodakaṃ prapatet | saptadhāsya mūrdhānaṃ sphoțayed a[rjakasyaiva mañjarī] | apy evānanda candrasūryāv apy evaṃ maharddhikau mahānubhāv evaṃ bhūmau nipatetām | apy 
evānanda | iyam mahāpṛthivī sahasā vi[cālaye]t | apy evānanda catvāro mahāsamudrā evaṃ gambhīrā | evaṃ vistīrṇāḥ | śoṣaṃ gaccheyuh | apy evānanda sumeruḥ parvatarājā sthānād vicālayet | na caitad anyathā syāt | ebhị̣ khalv ānanda mahādhāraṇimmantrapadaị̣ | śuṣkavṛkṣasyāpi śāntim svastyayanaṃ kṛtvā daṇḍaparihāraṃ pratisaraṃ bandhayet | patrāṇy asya jāyeyụ̣ pallavāni pravālāni puṣpāni phalāni ca jāyeyuh | kaḥ punar vādaḥ sa vijñātake mānuṣyake śarīre | sthāpayitvā <21r> ānanda paurāṇakakarmavipākam || idam avocad bhagavān āyuṣmān ānandas te ca bhikṣavaḥ sadevamānuṣāsuragaruḍagandharvaś ca loko bhagavato bhāṣitam abhyanandann iti || ||

\section{Ārya-mahādhāraṇī samāptā || ||}

[30] namo bhagavatyai ārya-buddhahṛdayāyai || evaṃ mayā śrutam ekasmin samaye bhaga[vān] tathāgatagocare viharati sma || ratnavyūhamaṇḍalamātre bodhisattvabhavane sarvākāravaropete sarvadharmaśabdā++++ | aneke bodhisattvasahasrair nānābuddhakṣetrebhyo 'bhyāgataị sarvais tathāgatadharmarājaputrais tatra khalu bhagavān vistīrṇā parṣa++++++++++++ buddhahṛdayā-nāma-dhāraṇī gañgānadīvālikāsamais tathāgatair bhāṣitā mayāpy etarhi bhāṣitā | saṃtrāsitā <21v> ++++++++++++++++ bhaviṣyati | ye 'pi kecit kulaputrā imaṃ dharmaparyāyam udgrahiṣyanti | dhārayiṣyanti | vācayișyanti | parebhyaś ca vistareṇa saṃ++++șyanti | +++ jātismarā bhaviṣyanti | na ca te durgativinipāta gamiṣyanti | kalpasahasraṃ ca taih saṃsārāḥ paścānmukhīkṛtā bhavișyanti | +nuttarāṃ samyaksambodhim abhisambhotsyante | sarvasattvāś ca rakṣanti | sarveșām ca priyā bhaviṣyanti | amanuṣyāṇāṃ manuṣyāṇāṃ ca | na paropakrameṇa kālaṃ kariṣyanti | na caiṣām māraḥ pāpīyān avatāram pratilapsante | tatra mārakāyikā devatāḥ saṃtrāsam āpadyante | deśo deśaś ca prapalāyiṣyanti | ta++ni mantrapadāni bhavanti | sarvabuddhānujñātāni | tadyathā buddhe buddhamati | sarvabuddhānujñāte || buddha buddha buddha buddha buddha buddha buddha || 7 \| ananto buddhaviṣayạ̣ | <22r> anantā dharmadesanā | ekānta manasikārạ̣ | saṃkṣepeṇa sarvabuddham eșā sarvatathāgatair dhāraṇi saṃprakāśitā | anekadhā vācayā yayā sarvasattvānāṃ dharmo deśitaḥ | tadyathā hara 2 cala 2 saṃcala 2 saṃtala 2 | tala 2 saṃtala 2 hiranye 2 hiraṇyasamariṇye | raṇapati 2 lokadhāre 2 dhara 2 pāra 2 dhāra 2 mahāvi++vāhite | hana 2 mama sarvaduṣțān | sarvabuddhapreșite | sarvapathe |

13 ratna-] $p c . ;$ āratna- $a c$. 
sadāparājite | pratibhānasaṃpanne | sattvāvalokite | sarvabuddhapratimaṇḍite | +++++++ 2 prasara 2 sarvadoṣāpagate svāhā ||

samanantarabhāṣite 'yaṃ vidyārāje | atha tāvad eva sarvāvatī bhūmi saśailavanakānanā++++++++++++ḥ kṣubhitāḥ | sumerụ̣ prakampitaḥ | kampitāni mārabhavanāni | saṃtrastā mārakāyikā devatāḥ | māraś ca pāpīyān du<22v> ++++++++++ āḥ pramuditāḥ sarve 'rthinaḥ praviśanti | ye cemāṃ dhāraṇịm dhārayiṣyanti | vācayiṣyanti | pustakagatāṃ vā | sarve te svastinā tena kuśala +++țavīkāntāraṃ nistariṣyanti | namo bhagavate atītānāgatapratyutpannebhyaḥ sarvatathāgatebhyo bhagavadbhyạ̣ || idam avocad bhagavān āttamanā +++ bodhisattvā bhagavato bhāṣitam abhyanandann iti \|

Ārya-buddhahṛdayā-nāma-dhāraṇī samāptā ||

[31] namo ratnatrayāya || namaḥ samantabhadrāya bodhisattvāya mahāsattvāya |

tadyathā smṛtivardhanīye anukampāṃ me kuru | āryasamantasmṛtivardhani | smṛtidhāraṇi | smṛtisaṃdhāraṇi me dadasva | anukaṃpām upādāya padme jihvendriyam viśuddheta | smṛtīndriyaṃ vardhana | vīryendriyadṛ̣haṃ syāt | tadyathā curu 2 kuru 2 muru $2<23$ r > muru 2 mama kaścid vihețhako bhavet | samantabhadrābhāṣitā svāhā || aruṇodgamanakālasamayena yasya vā tasya vā dantakāṣṭham ekaviṃśativārān parijapya bhakṣayitavyam || șoḍaśadivasāny avicchedena dine dine ślokaśatam gṛhṇāti dhārayati || ||

Ārya-samantabhadrā-nāma-dhāraṇī samāptā ||

[32] namo bha[gavatyai] āryadhātukaraṇḍāyai || oṃ bhūḥ tribhuvanavare | cacare | vacare | dhara 2 sarvatathāgatadhātudhare | padmasambhave | jayavare | 25 || mucule|+++ tathāgatadharmacakrapravartanavajro bodhimaṇḍalaṃkārākṛte | sarvatathāgatādhișțite | bodhaya 2 bodhani 2 sambodhani 2 budhya 2 sambodhaya $2++++++++++$ sarvāvaraṇāni | sarvapāpavigate | huru 2 sarvaśokavigate | sarvatathāgatahṛdayavajriṇi | sambhara 2 sarvatathāgatoṣnịṣa<23v > +++++++++++++ tathāgatādhișthitadhātugarbhe svāhā | sarvatathāgatasamayādhișțhite svāhā || sarvatathāgatahṛdayamudre svāhā | supratișṭhitastūpe svāhā +++++dhișthite kuru 2 svāhā || oṃ sarvatathāgatoṣṇịsadhātumudre svāhā || sarvatathāgatadhātuvibhūṣitādhișțhite hūṃ hūṃ svāhā ||

13 namah] $p c$.; nama $a c$. 
samanantarabhā++ca bhagavatā iyaṃ sarvatathāgatādhiṣthāna-guhyādhātukaraṇḍakamudrā-dhāraṇī samantaṃ daśasu dikṣu | ekaikasyāṃ diši navanavatilabimbasamā[na me] tathāgatakoṭiniyutaśatasahasrāṇi samāgatāny āgatya ca bhagavataḥ śākyamuniḥ sādhukārāṇy adaduḥ | sādhu sādhu śākyamuniḥ yas tvam īdṛśam dharmaparyāyaṃ jambudvīpe pratișthāpayasi |

Ārya-dhātukaraṇ̣̣ā-nāma-dhāraṇī samāptā || ||

[33] namo bhagavatyai ārya-rucirāngayașțau || namo vipulavi<24r>++[supra]tișthitāsaṃkhyeyastūpasahasrātirekaprabhāsitamūrtaye | mahāmaṇimukuțakuṇḍaladhārine | bhagavate padmapāṇaye sarvalokāyāpaśamanāya || vividha++++veśāvișțasattvaparimocakāya || tadyathā oṃ bhūr bhuvaḥ svaḥ | mahālokakaraṇe | tamastimirapațalavināśakāya || rāgadveșamohajālanā++++maka | rakșaka | sarvalokāpāyadurgatipraśamaka | sarvatathāgatasamavadhānakara | he he mahābodhisattva varada | padmalokasambhūta mahā[kāru] ṇika jațāmakuțālaṃkṛtaśira maṇikanakarajatavaidūryālaṃkṛtaśarīra | amitābhajinakamalālaṃkṛtapravara | naranārījanaśa+++++++++++dhisattva | vidhama 2 vināśaya 2 mahāyantrakleśakavāțabaddha saṃsāravāraka praśamanakara | purușapadma | purușanāga | purușasāga<24v>+++++++++++++ta | dhama 2 sama 2 dhuru 2 praśvāsaya 2 praśvāsaka 2 piri 2 viri 2 ciri 2 guru 2 muṣa muṣa muñca 2 vidhuna 2 dhuru 2 gāya 2 gādhaya 2 praha +++++++++++++ 20 ruṭi 2 mahāmaṇḍalakaraṇaśatapraveśikāvabhāsaviśamaka | mahābodhisattva varaṃ dada svāhā $\|$ iyaṃ bhagavataḥ padma++rucirāngayaștí-nāma-dhāraṇī mahāvajravilasite bodhisattvaprāsādavare | samupagītā mahādevanāgadānavakiṃnare saṃstutā | sarvāśāṃ śānti++vipulamahāparvatapraśamanī | ye kecic chroṣyanti | dhārayișyanti | vācayiṣyanti | pațhiṣyanti | dṛștyā vā sunirīkșișyanti | teșāṃ karmāvaraṇāni pra[śamam] yāsyanti | kālyam evotthāya sakṛt paṭheta padmapāṇi teșāṃ pṛșthatạ̣ samanubaddho bhavati | cintitamātreṇa sarvakarmāṇi sidhyanti | manasepsitāni yāni

[Rucirāngayaș̣ị-nāma-dhāraṇī]

1 -ādhișțhāna] corr.; -ādhișțhān $p c$. -ādhișțin $a c . \quad 7$-yașțau] corr.; -yayau ms. 13 -praśamaka] corr.; -praśamak ms. 15 -śira] corr.; -śiraḥ ms. 15 -śarīra] corr.; -śarīraḥ ms. 16 -pravara] corr.; -pravaraḥ ms. 16 -sattva] corr.; -sattvaḥ ms. 17 -kavāṭa-] corr.; -kavāpa- ms. 30 Continued on $36 r$. 
[34] <25r>mantāvalokitaguhya | āgaccha āgaccha | bhagavān | vīra vīra | mahāvīra | maṇikanakavajravaidūryamarakatapadmaparamarāgendranīlamahāmaṇimuktikāvibhū+++++ mahāpadma+++++++varada varadāyaka jvala jvala jvālā samantāvalokite āgaccha āgaccha bhagavan śīghraṃ samayam anu[sma]++++++ [dhara] yamavaruṇakuveranamaskṛta îsvara maheśvara padmeśvara | lokeśvara | ehy ehi bhagavan śīghram āgaccha | āgaccha | sarva $++++++\mathrm{m}$ anusmara darśaya svarūpam | vividhate[jadha]ra | samantaraśmijvālāgarbhaśarīra mahākāruṇika | [saumyo]mukha paripūrṇacandramaṇḍala++++ndrajața | amitābhamakuțadhara | mahābrahmaveșadhara | trilocana $++++++++++++++++\mid$ padmapāśa $++++++++++<25 \mathrm{v}\rangle++++$ ka namo 'stu te svāhā ||

dvādaśaśatavārān haste guggula gṛhītvā pari[japtavyaṃ] | tatạ̣ sidhyeti punạ̣ | așțottaraśatavārān parijapya dhūpaṃ dātavyaṃ +++++rakasyāgrataḥ | maṇụalakam kṛtvā japtavyam | ++++++ darśayati ||

[35] ++++[vatyai] āryaviśeșavatyai || evaṃ mayā śrutam ekasmin samaye bhagavān pāravate viṣaye | śimcā nāma nagarạ̣ gomino [nāma vihāraḥ] nāgamo varṣaḥ | mārgaśīrśe māse kṛ̣ṇapakṣe pañcamyāṃ vapakhyāto nāma bhikṣuh | gaṃso nāma nagaram | cīnanagaroc ca[t]urbhir yo[janai] r atha mārgaprātisyottare sa bhikṣuh paśyati dūrato mahākāyaṃ puruṣaṃ triṃśadvitastipramāṇam | caturvitastimukhamaṇụalam | dṛstvā ca vapakhyānasya bhikṣa

\section{[Viśeșavatī-dhāraṇī]}

[36] <26r> ekākī pravivekasthito buddhamanasikāram āmukhīm ālambya bhagavantam padmahastam anusmṛtya saptavārān āvartayet | yathepsitam labhate | sarvalokapriyaś ca bhavati | sarvadurgatayaś cāsya ruddhā bhavanti | muhūrtaṃ ca hy eme sthito manasi-m-āhvayet | anekajanmakoṭisamcitaṃ karma naśyati | cakravartim upagacchati | tena mahāpuṇyaskandhena samanvāgato bhavișyati | jātau jātau yāsāṃ padmakulạ̣ pratilabhate | viśiștajanmasampadaś ca bhaviṣyati | sugandhapuṣpam añjaliṃ kṛtvā [saṃdhū]- 30 pyāvalokiteśvarasyāgratạ̣ saptavārān āvartayet | mahāguṇasahasraṃ pratilabhate | mahākaruṇā cālokabhūtā bhaviṣyati | mahādhanasamanvāgataś

1 Seemingly not this folio follows. 7 -dhara] corr.; -dharah ms. 20 yojanair] corr.; yojanai | r ms. 20 sa] corr.; sar ms. 23 Continued on 35r. 24 Seemingly not this folio follows. 
ca bhavișyati | tasyaiva mukham avalokayan japet | tata prahasitavadanam āryāvalokiteśvarasya syāt | dṛșțamātreṇa ca vimalakarī nāma prathamaṃ <26v> dharmāvalokamukhāvabhāsanām pratilabhate | ihaiva janmani buddhānusmṛtiḥ pratilabhate | samāhitacittaḥ kālaṃ kariṣyati | sarvatra jātau jātau jātismaro bhaviṣyati | [ya]thepsitāni ca pratilabhate | sarvakarmāvaraṇāni kṣapayiṣyati | pūrvaṃ tu pañcadaśyāṃ gṛhītopavāsaḥ | śuklāmbaradharaḥ sadhātuke caitye pratimāyām agrataḥ śvetacandanamayaṃ maṇụalakam upalikhya vividhaprakāraị̣ puṣpair mạ̣ḍalakam avakīrya sugandhapuṣpadhūpagandhair bhagavantạ̣ satkṛtyāryāvalokiteśvaraṃ tatheva cāṣțaśatam āvartayet | tatạ̣ sarvāpāyavigato bhavati | anantāpakārī suvistīrṇapāpaḥ supariśuddhakāya vānmanaḥ pracāraś ca bhavati | satatasamitạ̣ ca samādhibalābhiṣekabalabhūmipāramitābhiśekajñānabala upasaṃhriyante | ūrdhvam avalokan japed devo varṣati | mahīm avalokayan japet sarva+

[37] <29r> viśeșavatī ca dhāraṇī anusmārayitavyā | saptadivasaṃ cāṣṭāngasamanvāgatam upavāsayitavyā || namo bhagavate vipulaviśuddhigambhīragarjitarājāya tathāgatāya || tadyathā om vipulagarjitavipulasvare vipulayonișe | alagate svāhā || namaḥ sarvanivaraṇaviṣkambhiṇas tathāgatasya | tadyathā he mahe mahāmahe 20 svāhā | namo guṇākarasya tathāgatasya | tadyathā gaganākare | gaganasambhave | gaganakīrtite svāhā || namaḥ samantagandhottamasya tathāgatasya | tadyathā | samaye svāhā || namo aparājitagarjitagāminas tathāgatasya | tadyathā | amāmahe svāhā || namo mānastambhasya tathāgatasya | tadyathā | mānaviśuddhe | îśvare | padmasambhave | kiṃkare | hitaṃkarīye svāhā || namaḥ sarvabuddhabodhisattvānām | nama āryamañjuśriyaḥ | tadyathā | jaye | jayalabdhe | he mahe mahā<29v>mahe svāhā || nama āryāvalokiteśvarasya | tadyathā | gaganāọhye | gaganasambhave | gaganamadhye | gaganavikrānte | avikrānte | ehi me svāhā || nama āryasamantabhadrasya | tadyathā | he bhadre | mahābhadre | amṛtabhadre | vigatarajase | mahāvigatarase svāhā |

6 kṣapayișyati] corr.; kṣapiyișyati ms. 12 -ābhiśeka-] corr.; -ābhiśeșa- ms. 16 Continued from 35v. 20 -viṣkambhiṇas] corr.; -viṣkabhiṇas ms. 25 aparājita-] pc.; aparājitā-ac. 28 -śriyaḥ] corr.; -śriyaṃh ms. 31 gagana-] corr.; gana- ms. 
nama āryavimalakīrtị̣ | tadyathā | kīrtitaḥ | sarvajinair abhi[kīrti]taḥ | sarvabuddhair vajrabhedakare | vajrasambhave svāhā || namaḥ sarvabuddhabodhisattvānām | tadyathā | śvetakarabhe | jvalanīye svāhā || jambhani | stambhani | mo[hani | puṇụar]īkāye svāhā || mohadanti jambhanīye svāhā || dūravidūri kālavikṛte svāhā | sāntesvine nirvāpanīye svāhā || dūravidūrīye svāhā || lambacūụāya svāhā || sarvakarmābhișiktāya svāhā || lohitavihitāya svāhā || ajñānavidhamanīye svāhā || dhātukarīye svāhā || meghasphoțanìye svā<30r>hā || baladantīye svāhā || bodhyangadantīye svāhā | dharmasādhanikāye svāhā || ekaromāya svāhā || amoghacāriṇiye svāhā || brahmopaguhāya svāhā || sarvakarmābhiṣiktāya svāhā || sarvabuddhābhisaṃskṛtāya svāhā || ekaśṛngāya svāhā || aśṛngāya svāhā || bhūtāya svāhā || abhūtāya svāhā || sarvaduḥhopaśamanāya svāhā || ayam asyā vidyāyā vidhị̣ | saptāham | sapta sapta bhikṣavo bhojayitavyāḥ | rātrau cāgnị̣ prajvālayitavyạ̣ | triṣu ratneșu prasādaḥ karạ̣iyaḥ | ya evaṃ kariṣyati sa vyādhito vimokṣyati | punar api mañjuśrīkumārabhūta āha | yah kaścit kulaputro vā kuladuhitā vā | imạ̣ dharmaparyāyaṃ dhārayiṣyati | vācayișyati | parebhyaś ca vistareṇa samprakāśayișyati | sa vyādhito vimokṣyati | punar api mañjuśrīkumārabhūta āha | ayạ̣ dha<30v>rmaparyāyo deśād deśaṃ nagarān nagaram | grāmād grāmaṃ netavyạ̣ | yathā sarvajanasya śrotāvabhāsaṃ gamiṣyati | punar api mañjuśrīkumārabhūta āha | ya imạ̣ dharmaparyāyam ekavācikayā parivartișyati | sa anenaiva vimokṣyati | ya dvivācikayā parivartayiṣyati sa putradāreṇa saha vimokṣyati | yas trivācikayā parivartayișyati | sa sakalabandhuvargeṇa saha vimokṣyati | yaś caturvācikayā parivartayișyati | sa sarvarāṣțram vimokṣayiṣyati | yaḥ pañcavāri[kayā] parivartayiṣyati | sa sāmantakaṃ rāșțraṃ vimokṣayiṣyati | punar api mañjuśrīkumārabhūta āha | ayaṃ dharmaparyāyaḥ śīghram evānyadeśam upa[nīya] prakāśayitavyaḥ || tadāpy ete guṇạ̄ sambhaviṣyanti | yaś cemāṃ dharmaparyāyam na dhārayen na vācayen na pareșām vistareṇa saṃprakāśayet | nānye deśāntaragatạ̣ ku

[Viśeșavatī-dhāraṇī]

[38] <32r>kadhātuṣūpapadyata iti || ||

Ārya-karṇajāpā-nāma-dhāraṇī samāptā || ||

9 -cārinīye] pc.; -cārāṇīye $a c .15$ mañjuśrī-] corr.; majuśrī- ms. 26 deśam] pc.; -deśeam ac. 31 Seemingly not this folio follows. 
[39] namo ratnatrayāya || nama āryāvalokiteśvarāya bodhisattvāya mahā[sattvā] ya mahākārunikāya tadyathā oṃ ratne ratne mahāratne ratnavatīye svāhā || || ekavāroccāritamātreṇāpi lakṣacaityavandanā puṇy+++++tīit ||

Ārya-caityavandanā-nāma-dhāraṇī samāptā || ||

[40] [siddham] evaṃ mayā śrutam ekasmin samaye bhagavān sukhāvatyāṃ viharati sma | a[tha kha]lu bhagavān mahāśriyaṃ dṛ̦țvā mañjuśriyam āryāvalokiteśvaraṃ ca bodhisattvaṃ mahāsattvam etad avocat | yaḥ khalu punar mañjuśrīr mahāśriyo devatāyā nāmadvādaśakaṃ śrosyati | bhikṣur vā | bhikṣuṇī vā | upāsako vā | upāsikā vā | anyo vā yaḥ kaścid dhārayiṣyati vācayișyati | likhișyati | likhā<32v>payișyati | na tasya dāridryabhayaṃ bhavișyati | dāridrya prahāya āḍhyo bhaviṣyati | atha khalu bhagavān mahāśriyo devatāyā nāmadvādaśakaṃ bhāṣate sma | tadyathā oṃ la[kșmīḥ] | śrīḥ | padmamālinī dhanādhipatị̣ | gaư̄i mahāyaśā padmanetrī | kartī mahādyutiḥ | annadāyinī | ratnaprabhā | mahāśrîś ceti | atra mantrapadā++ [hili 2 mili 2] kāyaviśodhani | vāgviśodhani | manaḥsaṃśodhani | sisi sisi | nimi 2 alakșmāṃ me nāśaya svāhā || trijaptā kartavyā || +++++++++++sya sarve pratipakṣā vināśaṃ yāsyanti | subhagaś ca bhaviṣyati | rājadarśane vācayitavyaḥ rājā tasya vaśo bhaviṣyati | putrasaṃjñāṃ ca dadāti yat kathayati tat karoti | satatajāpena mahābrahmā āgacchati | āgatya ca yam icchati taṃ varaṃ dadāti | idam avocad bhagavān [āttamanā ma]<33r>[ñju]śrīr āryāvalokiteśvaraś ca bodhisattvo mahāsattvaḥ sā ca sarvāvatī parṣat sadevamānuṣāsuragandharvaś ca loko bhagavato bhāṣitam abhyanandann iti || ||

Ārya-mahā[śrī]-nāma-dhāraṇī samāptā || ||

[41] [siddham] namo lokanāthāya || rajanī | nimbhapatrāṇi | piṣyalī | marīcāni ca | vidraṅgam | bhadramustạ̣ ca | saptamaṃ viśvabhe[șa]jam || etāni samabhāgāni gomūtreṇa pīṣayet | kalāmātragulikaṃ kṛtvā chāyāśuṣkaṃ ca kārayet | namo ratnatrayāya | nama āryāvalokiteśvarāya bodhisattvāya mahāsattvāya mahākārunikāya |

9 devatāyā] corr.; devatāṃyā ms. 24 abhyanandann] corr.; abhyanandan ms. 26 lokanāthāya] corr.; lokanāya ms. 
tadyathā āte jāte ciri 2 caṇḍāi svāhā ||

anena mantreṇāṣțaśatābhimantritam kṛtvā gulikạ̣ sthāpayet | anenaiva mantreṇa saptābhimantritạ̣ kṛtvā sarvavyādhiṣu prayoktavyā | nityajvare pānīyenāṃ japet | dinatrayam | viṣama<33v>jvare gomūtreṇāṃ japet dinatrayam | ekāhikadvyāhikatryāhikacāturthakasthātmarudhireṇāṃ japed dinatrayam | akṣiśrāve śiśireṇāṃ japed dinatrayam | sarvatrākṣiśūle 'jāmūtreṇā japet | vāsyodakena vā | akṣitimire strīkṣīreṇām japet saptāhatrayam | piṣțake gomūtreṇā japet saptāham | akṣikha+ke strīkṣīreṇa saptāham añjayet | pațale 'jamūtreṇa saptāham añjayet | rātryāndha tathaiva ca | apsaragṛhīte 'jamūtreṇām japet | bhūtapreta[piśāca] ḍakinīgṛhīe +rapā japet | bālagrahe surayā tatkṣaṇaṃ naśyati | nākāśe bhṛngarājarasenāñjayed dinatrayam | dantaśūle yam ca va+++++++ṇakapoladhāraṇaṃ dinatrayam kuryāt | mukhapāke gulikātrayaṃ divārātrau dinatrayam | śiroroge saptagulikāḥ $\mathrm{ka}++++++\mid$

[42] <35r>s taṃ tādṛ́am rūpam etad abhavat | mahākāyo vatāyaṃ puruṣaḥ | vyaktam ayaṃ mañjuśrīkumārabhūto bhaviṣyatīti | sa ubhau jānumaṇụalau pṛthivyām pratișțhāpya yena sa mahākāyaḥ puruṣas tenāñjalim praṇamya tam mahākāyam puruṣaṃ etad avocat | kiṃ tvaṃ mañjuśrīkumārabhūta iha saṃdṛ́yase | mañjuśrīr āha | iti hi bhikṣo jambudvīpe sattvānāṃ vyādhaya utpannāḥ | yakṣāsuragaruḍagandharvāḥ sumeroḥ parvatarājasya ekapārśve sthitās tena candrasūryaryoḥ prabhā na prajñāyate | candrasūryagrahanakṣatrāṇi ca gaganāntareṇa saṃdṛśyante | sadevāsuraś ca saṃrāmaḥ | pratyusthitaḥ | saṃgrāmābhirūụhāś ca devāḥ parājitāḥ | asurāṇāṃ japaḥ | tadā bhūtapiśācāḥ | strīrūpeṇa sattvānāṃ glānyam anuprayacchanti | tadyathā | galagraha | lūtavaisarpodaraśūlam | jvaram e<35v>kāhikam | dvitīyakam | traitīyakam | cāturthakam | vātikam | paittikam | ślaișmikam | sāṃnipātikam | śirahśūūlam | piṭaka | pāmā | atisāra | cakṣurogādīn apanayanti | tadyathā | atiṿ̛ștyanāvṛṣṭikāle vṛștibhị̣ sasyasampattīnām ojograhaṇam āyurvarṇaprahaṇam || tadyathā jambudvīpe sattvānāṃ nānāvyādhiparipị̣itānāṃ caṇḍasiṃhavṛkavyāghravyālarūpeṇa sattvānām

4 Marginal addendum: galagaṇḍa ajasvīneṇa sapta guḍikādena trayạ̣ pātavyā ॥ mahāsamudrottaraṇe pațe vardhāmukhe prakșayet sukhenottarati 7 pișțake] corr.; picūțake ms. 11 tatkṣaṇaṃ naśyati] corr.; tatkṣaṇasyati ms. 16 Continued from $25 \mathrm{v} .16$ abhavat |] corr.; abhavatā ms. 24 saṃgrāmābhirūḍhāś] corr.; sagrāmābhirūḍhāś ms. 28 -rogādīn] corr.; -rogādīnn ms. 29 -sampattīnām] corr.; -sampattīnāṃm ms. 31 -vyāla-] corr.; -vyāhari- ms. 
ojo haranti | jambudvīpakānāṃ sattvānām akālavināśaḥ pratyupasthitaḥ | duḥkhena sattvānāṃ vyādhivimokṣaṇaṃ bhaviṣyati | iha jambudvīpe sattvānām vịddhamadhyaharāṇāṃ triṃśadbimbarāṇi vinaśyate || tasmāt tarhi bhikṣo jambudvīpakānāṃ sattvānāṃ kuśalamūlaviṿ̛ddhaye yatna karaṇīyaḥ triṣu ratneṣu prasādaḥ karaṇīyah | devatārcanaṃ ca karaṇiye | gandhapuṣpeṇa caiṣāṃ pūjā karaṇa[yā]

\section{[Viśeșavatī-dhāraṇī]}

[43] <36r> [syāni] sampadyante | sarittaḍagapuṣkiriṇīm avalokan japed udakaṃ prādurbhavati | sarvavyādhīna hastenāvamṛ[da]yana japet | vyādhaya uda gacchanti | mușitasmṛtir agrato ja+++[smṛtim] pratilabhate |

Ārya-rucirāngayaștị-nāma-dhārạ̣ī samāptā || ||

[44] namo buddhāya || namaḥ sarvamaṅgalatithimuhūrtanakṣatrarājāya tathā[gatā]yārhte samyaksambuddhāya \| tadyathā | oṃ nakṣatre 2 sarvamangalatithimuhūrtanakṣatrāṇi | sarvārthasādhukāraṇī bhavatu svāhā || yāṃ diśiṃ ++kāmas tāṃ diśam avalokya 15 iyaṃ dhāraṇī paṭitvāgamyate mahāsiddhi bhavati ||

Sarvamaṅgalā-nāma-dhāraṇī samāptā || ||

[45] namo herukāya || krodhapingalalocanāya || sahasrajyoti dhara dhara jvala 2 prajvala 2 triśūlavyagrahasta sara sara | prasara prasara | śūra śūra hasa hasa || gṛhṇa gṛhṇa | gṛ<36v>hṇāpaya gṛhṇāpaya | bhrāma bhrāma | bhrāmaya bhrāmaya | sarvadușțasattvānām | nāgānām | nāgarājānām | sarpāṇāṃ mukhaṃ kīlaya kīlaya | bho bho krodheśvara śūlaṃ nāśaya nāśaya | gulma nāśaya nāśaya | plīhīṃ nāśaya nāśaya | aśmarīṃ nāśaya | mūtrakṛcchraṃ nāśaya nāśaya | anāmakaṃ nāśaya nāśaya | durnāmakaṃ nāśaya | evạ̣ sarvā[n rogān] nāśaya nāśaya | ekāhikam | dvyāhikam | tryāhikam | cāturthakam | suvarṇajvaram | kapotajvaram | indrajvaram | mahendrajvaram | vātikam | paittikam | śleșmikaṃ sāṃnipātikam | māsārdhamāsikam | sāmvatsarikam | evaṃ sarvān rogān nāśaya nāśaya nivāraya nivāraya | hūṃ mama sarvasattvānāṃ ca śānti kuru svāhā || ||

3 trimśad-] corr.; triśad- ms. 7 Continued on 29r. 8 Seemingly not this folio follows. 24 anāmakaṃ] corr.; annāmakaṃ ms. 24 nāśaya] corr.; nāśaye ms. 26 śleșmikaṃ] $p c$; śleșmi $a c$. 
Sarvarogapraśamanī-nāma-dhāraṇī samāptā || || āryavajraśisskharodbhavatantrād uddhṛteyam ||

[46] oṃ namas tribhuvaneśvarāya || maheśvarāya | dhara dhara sa

[Unidentified text]

3 -bhuvaneśvarāya] corr. -bhuvaneśvośaya ms. 

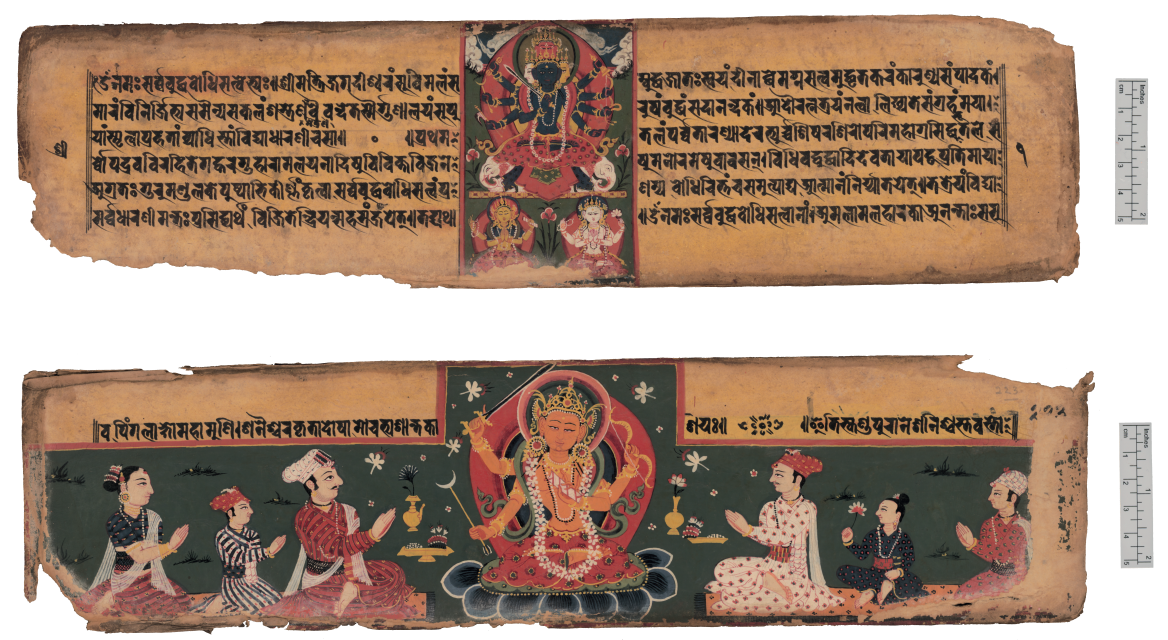

Figures 3 and 4: Dhāraṇīsaṃgraha manuscript MS ADD 1326, folios 1v (top) and 223v (bottom). The former depicts Mahākṣobhya and the latter the donor's family with Mañjuśrī in the middle. Copyright ( $)$ Cambridge University Library. Licensed under Creative Commons Attribution-NonCommercial 3.0 Unported License (CC-BY-NC 3.0). Used with permission. 